OECD Economics Department Working Papers No. 1168

Christine Lewis,

Investment Gaps after

Nigel Pain,

the Crisis

Jan Stráský,

Fusako Menkyna

https://dx.doi.org/10.1787/5jxvgg76vqg1-en 
Organisation de Coopération et de Développement Économiques

Organisation for Economic Co-operation and Development

14-Oct-2014

ECONOMICS DEPARTMENT

English - Or. English

\section{INVESTMENT GAPS AFTER THE CRISIS}

ECONOMICS DEPARTMENT WORKING PAPERS No. 1168

By Christine Lewis, Nigel Pain, Jan Strasky and Fusako Menkyna

OECD Working Papers should not be reported as representing the official views of the OECD or of its member countries. The opinions expressed and arguments employed are those of the author(s).

Authorised for publication by Jean-Luc Schneider, Deputy Director, Policy Studies Branch, Economics Department.

All Economics Department Working Papers are available through OECD's Internet website at http://www.oecd.org/eco/Workingpapers

Complete document available on OLIS in its original format

This document and any map included herein are without prejudice to the status of or sovereignty over any territory, to the delimitation of international frontiers and boundaries and to the name of any territory, city or area. 
OECD Working Papers should not be reported as representing the official views of the OECD or of its member countries. The opinions expressed and arguments employed are those of the author(s).

Working Papers describe preliminary results or research in progress by the author(s) and are published to stimulate discussion on a broad range of issues on which the OECD works.

Comments on Working Papers are welcomed, and may be sent to OECD Economics Department, 2 rue André-Pascal, 75775 Paris Cedex 16, France, or by e-mail to eco.contact@oecd.org

This document and any map included herein are without prejudice to the status of or sovereignty over any territory, to the delimitation of international frontiers and boundaries and to the name of any territory, city or area.

The statistical data for Israel are supplied by and under the responsibility of the relevant Israeli authorities. The use of such data by the OECD is without prejudice to the status of the Golan Heights, East Jerusalem and Israeli settlements in the West Bank under the terms of international law.

\section{(c) OECD (2014)}

You can copy, download or print OECD content for your own use, and you can include excerpts from OECD publications, databases and multimedia products in your own documents, presentations, blogs, websites and teaching materials, provided that suitable acknowledgment of OECD as source and copyright owner is given. All requests for commercial use and translation rights should be submitted to rights@oecd.org 


\section{ABSTRACT/RÉSUMÉ}

\section{Investment Gaps after the Crisis}

The downturn in fixed investment among advanced economies from the onset of the global crisis was unusually severe, widespread and long-lasting relative to comparable episodes in the past. As a result, investment gaps are large in many countries, not only in relation to past norms but also relative to projected future steady-state levels, with a gap of 2 percentage points of GDP or more in several countries. A significant proportion of this investment shortfall is attributable to soft demand conditions (the accelerator effect) but financial factors and heightened uncertainty have also played a role. In addition to continued support to demand from macroeconomic policies, the recovery in investment could be boosted by tackling longer-term policy issues that bear on investment decisions indirectly, by reducing financial fragmentation in the euro area and by undertaking growth-friendly structural reforms.

\section{JEL classification: D24; E22; G31; O16}

Keywords: Investment, cost of capital, balance sheets, uncertainty, economic outlook

************** $*$ *

\section{Écarts relatifs à l'investissement après la crise}

Le ralentissement conjoncturel de l'investissement fixe dans les économies avancées depuis le début de la crise économique mondiale a été exceptionnellement défavorable, répandu et persistant par rapport à des épisodes comparables ayant eu lieu dans le passé. En fait, les écarts relatifs à l'investissement sont considérables dans de nombreux pays, non seulement par rapport aux normes du passé, mais aussi par rapport aux niveaux futurs prévus de l'état d'équilibre, avec un écart de 2 points de pourcentage du PIB ou plus dans plusieurs pays. Une part importante de cet écart de placement est attribuable à des conditions de faible demande (effet d'accélérateur) mais des facteurs financiers et une incertitude accrue ont également joué un rôle. En plus d'un soutien continu de la demande par des politiques macro-économiques, la reprise de l'investissement pourrait être stimulée en luttant contre les problèmes de politique de long terme pesant indirectement sur les décisions d'investissement, en réduisant la fragmentation du système financier dans la zone euro et en mettant en œuvre des réformes structurelles favorables à la croissance économique.

Classification JEL: D24 ; E22 ; G31 ; O16

Mots clés : Investissement, coût du capital, bilans, incertitude, perspectives économiques 


\section{TABLE OF CONTENTS}

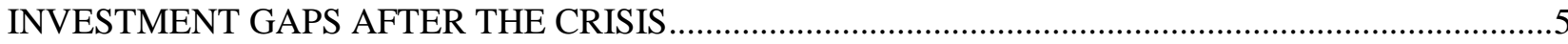

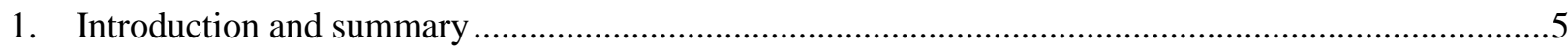

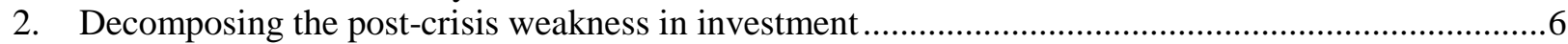

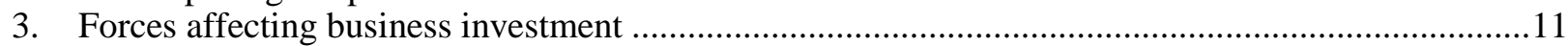

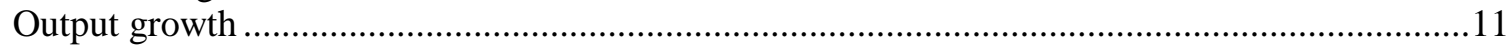

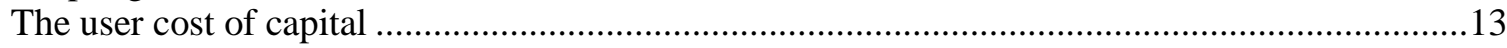

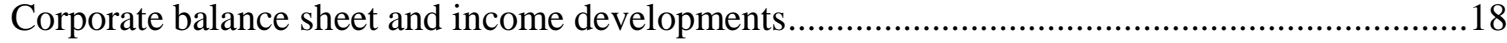

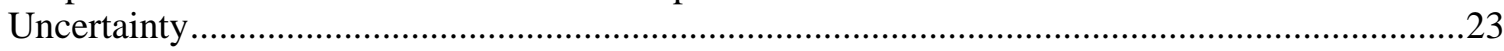

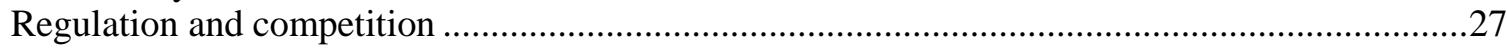

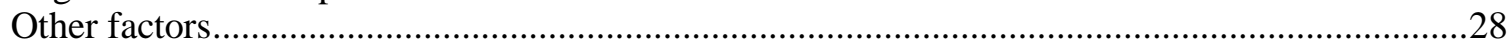

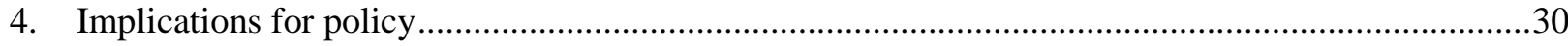

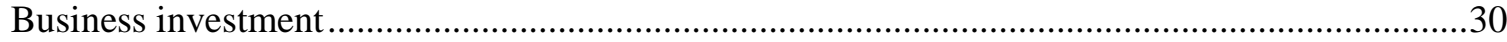

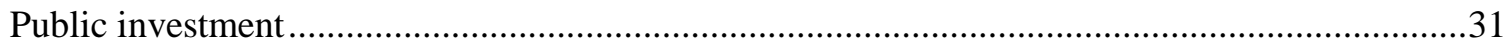

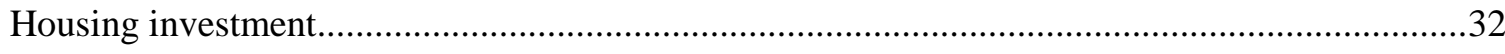

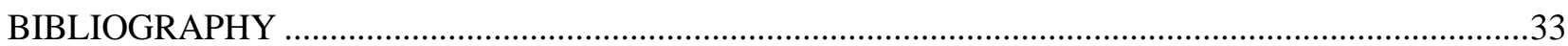

APPENDIX 1: A SIMPLE BASELINE MODEL OF BUSINESS INVESTMENT …................................36

\section{Tables}

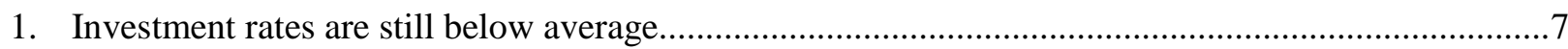

2. Significant changes have occurred in non-financial corporate balance sheets since the crisis began.20

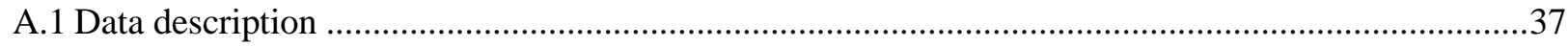

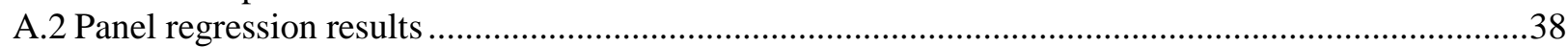

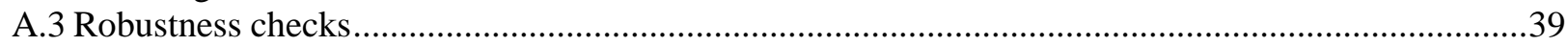

\section{Figures}

1. Investment has been weak by historical standards ........................................................................

2. Investment is low relative to pre-crisis averages in many OECD countries ....................................

3. Real business investment growth has been weak compared to previous cycles ..................................

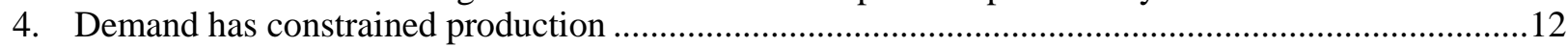

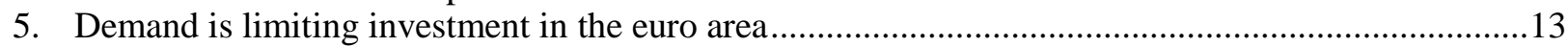

6. A simple accelerator model of growth in business investment .......................................................14

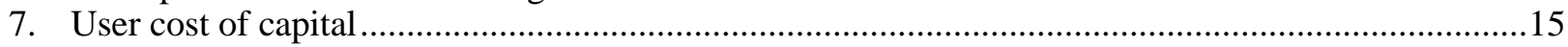

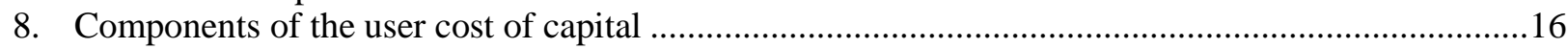

9. Bank lending rates have declined, but spreads have risen ....................................................17

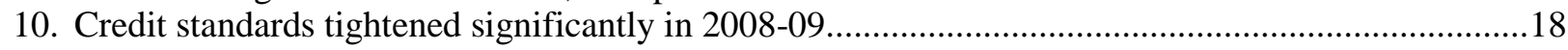

11. Non-financial corporations' gross bond issuance has risen recently ..........................................21

12. Growth in real corporate profits has been solid in the United States but weaker elsewhere................22

13. Financial factors have constrained investment in recent years ........................................................23

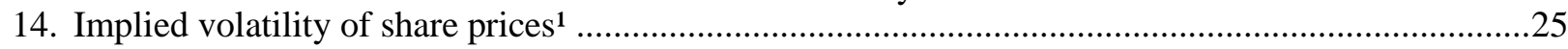

15. Measures of policy uncertainty have fallen but remain elevated ....................................................26

16. Regulatory and taxation issues appear to have added to uncertainty in the United States.................27

17. Product market regulation has fallen in some, but not all countries ..............................................28

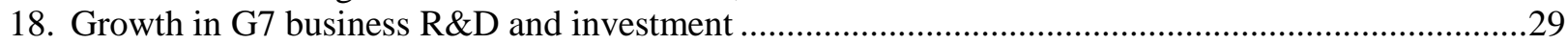

19. G7 FDI net outflows have risen relative to domestic investment since the crisis began .......................30

A1. Estimated contributions to the change in investment growth...........................................................40

\section{Box}

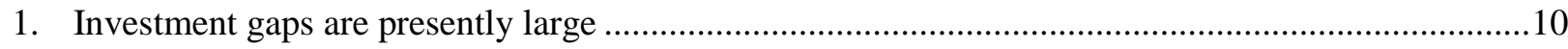




\title{
INVESTMENT GAPS AFTER THE CRISIS
}

\author{
By Christine Lewis, Nigel Pain, Jan Strasky and Fusako Menkyna ${ }^{1}$
}

\section{Introduction and summary}

1. The onset of the financial crisis resulted in a very sharp decline in fixed investment in many economies. Subsequently, the weak recovery in investment, especially business investment, has been an important factor limiting the momentum of the recovery. This paper looks at investment developments in the OECD economies since the start of the crisis, with the main focus being on business investment, and discusses the key factors that account for the weakness in investment and their policy implications.

2. The downturn in fixed investment among advanced economies from the onset of the global crisis was unusually severe, widespread and long-lasting relative to comparable episodes in the past. The recovery in fixed investment has also generally been sluggish compared to recoveries from past recessions. Consequently, investment gaps are large in many countries, not only in relation to past norms but also relative to estimated future steady-state levels, with a gap of 2 percentage points of GDP or more in several of them. Most of the current shortfall in total investment compared to pre-crisis norms is accounted for by weaker business and housing investment, with a small additional contribution from softer public investment.

3. A significant proportion of the business investment shortfall can be linked to demand (in a standard accelerator model). Business investment declined much more rapidly than output during the crisis and has subsequently recovered relatively slowly, especially following the intensification of the euro area crisis in 2011. The user cost of capital - another key determinant of investment in standard theoretical models - has fallen, thanks to monetary stimulus. It may now be only a limited constraint on investment growth for larger companies, but constraints on credit supply in countries with weak banking systems are likely depressing capital spending of small companies.

4. The analysis highlights two other important factors that can help to account for the weakness in business investment. The pre-crisis build-up of corporate leverage seems to have intensified the investment decline as the crisis got underway, and contributed to the subsequent sharp declines in corporate expenditure. Leverage has now declined substantially, suggesting this is not currently holding back investment. In addition, economic and policy uncertainty rose significantly during the financial crisis and again following the intensification of the euro area crisis, likely constraining investment growth, although there are signs this may now be easing.

5. The structure of this paper is as follows. The first section sets out cross-country developments in different components of fixed investment since the onset of the crisis. The following section discusses a number of important determinants of business investment, assesses the extent to which they can account for recent investment outcomes and likely prospects and reports estimates of longer-term investment gaps. A final section concludes by setting out a number of policies that could help stimulate investment.

1. At the time of writing the paper, Christine Lewis, Nigel Pain and Jan Strasky were in the Macroeconomic Policy Division and Fusako Menkyna was in the Office of the Chief Economist, OECD Economics Department. The authors wish to thank Jean-Luc Schneider, Sveinbjörn Blöndal, Geoff Barnard and other colleagues in the OECD Economics Department for comments on earlier drafts, Jérôme Brézillon and Ane Kathrine Christensen for statistical assistance, and Isabelle Fakih for assistance in preparing the document. 


\section{Decomposing the post-crisis weakness in investment}

6. The level of investment fell sharply during the financial crisis and has subsequently picked up only slowly, weakening the pace of the recovery in activity. A striking feature of the downturn during the crisis was that fixed investment fell in real terms in every OECD country between 2007 and 2010, which was not the case in the downturns of the early 1980s and the early 1990s. In the United States, investment (as a share of nominal GDP) is still over 3 percentage points below its pre-crisis level; a better outcome than in the Great Depression but considerably weaker than after the 1973-74 oil price crisis (Figure 1). In the United Kingdom, investment has been much more anaemic than during these previous episodes.

Figure 1. Investment has been weak by historical standards

Ratio of nominal investment to GDP, percentage points from pre-crisis ratio

\section{United States}

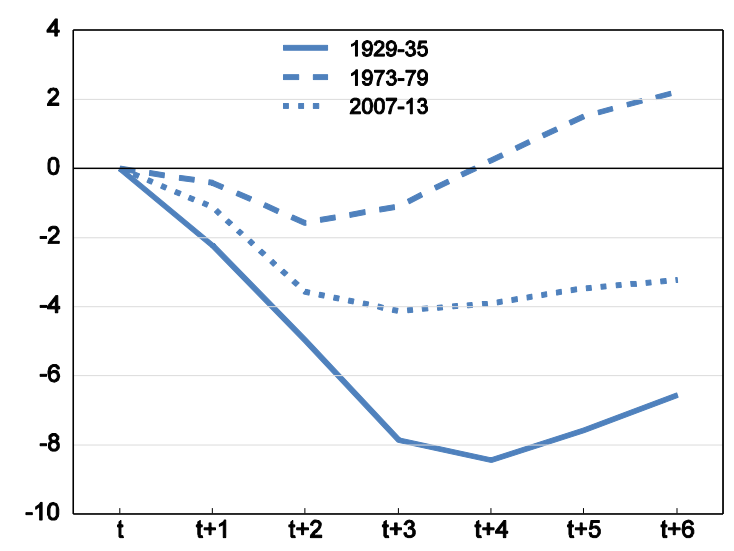

United Kingdom

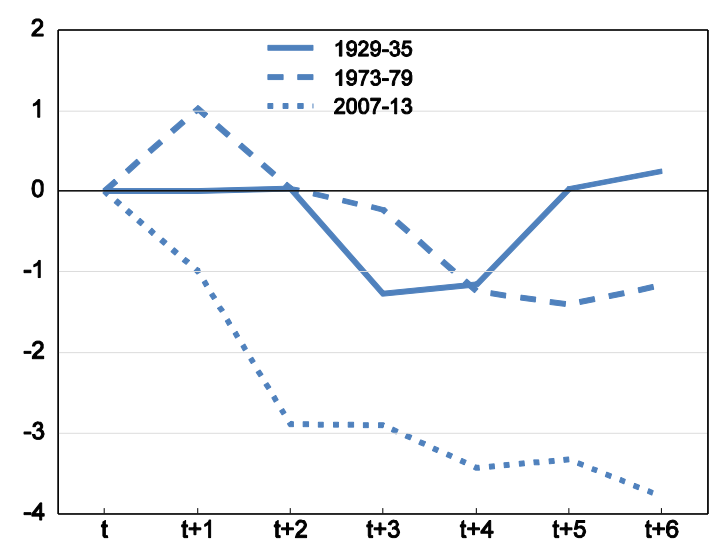

Note: Pre-crisis ratio is from the peak in real GDP: 1929, 1973 and 2007. Data are total investment except US data for 1929-35, which are private fixed investment.

Source: Bank of England; Bureau of Economic Analysis; and OECD Economic Outlook 95 database.

7. As a (nominal) share of GDP, investment in the OECD economies as a whole in 2013 was still $2^{1 / 2}$ percentage points below the pre-crisis average (1996-2007), and just $1 / 2$ percentage point above the trough in 2010Q1 (Table 1). A decomposition of investment into three components - housing investment, business investment and public investment - shows that business investment accounts for almost 1 percentage point of the "investment gap". Housing investment accounts for another percentage point of the gap, while the remainder is due to public investment. 
Table 1. Investment rates in 2013 were still below average

\begin{tabular}{lccccc} 
& $\begin{array}{c}\text { Pre-crisis average } \\
(\mathbf{1 9 9 6 - 2 0 0 7 )}\end{array}$ & Trough & 2013 average & Difference from Difference from \\
average & trough \\
\hline Total investment & 21.7 & 18.7 & 19.1 & -2.6 & 0.5 \\
Housing investment & 5.3 & 3.7 & 3.9 & -1.4 & 0.2 \\
$\begin{array}{l}\text { Business and public investment } \\
\text { of which: }\end{array}$ & 16.5 & 14.9 & 15.2 & -1.3 & 0.3 \\
$\quad$ Business investment & 12.7 & 11.0 & 11.9 & -0.9 & 0.9 \\
$\quad$ Public investment & 3.7 & 3.2 & 3.3 & -0.4 & 0.1 \\
\hline
\end{tabular}

Note: Based on data for 18 OECD countries for which all components of investment are available. The quarter of the trough for each type of investment differs, so the respective columns are not additive.

Source: OECD Economic Outlook database; and Authors' calculations.

8. The OECD average figures in Table 1 mask considerable disparities across countries, as shown by the dispersion of the distribution of country-level gaps for each component of investment (Figure 2). In the median economy, nominal investment in 2013 was around 2 percentage points below the pre-crisis average (1996-2007). The data by broad investment type reveal that:

- The ratio of both business and housing investment to GDP is below pre-crisis averages in a majority of OECD countries, typically by 1 and $1 / 2$ percentage point, respectively (Figure 2 ). Public investment, on the other hand, is closer to pre-crisis averages, in part reflecting different pre-crisis trends.

- Aggregating across economies, business investment - the largest component of investment and $12 \%$ of GDP - fell by around 21/4 percentage points of GDP between early 2008 and late 2009 . Around 1 percentage point of this decline was recovered by 2013. At this point, it was below its pre-crisis average in 13 of the 18 countries with available data. Investment has been strong relative to historical standards only in the resource-rich economies of Australia, Canada, Mexico and Norway.

- Housing investment, notwithstanding its small share in total investment (one quarter), also accounts for a large share of the overall swings in total investment. The mean decline lies well below the median, reflecting the large adjustment that has occurred in many economies that had strong over-investment in the pre-crisis years, during domestic house price booms. This implies that much of the subsequent decline may persist. In other economies, the declines are more likely to be cyclical, reflecting the changes in household incomes and wealth. There are some countries, such as Canada, in which investment has risen rapidly since the crisis, reflecting only a modest downturn during the crisis and the robust domestic housing market during the recovery.

- Public investment, the smallest of these investment components, is subject to different pressures: in aggregate, public investment in the large advanced economies actually rose relative to GDP between 2007 and 2009, in part due to fiscal stimulus measures enacted to stem the effects of the financial crisis. But as the crisis evolved to focus on sovereign debt levels, and many governments undertook significant fiscal consolidation measures, the level of public investment relative to GDP fell sharply until 2013. The shortfall relative to past norms is largest in the vulnerable euro area economies.

- There is a positive relationship between the gaps for each category of investment. This might reflect the common roots of the crisis in the financial and housing sectors and the subsequent transmission to public sector finances. Some of the largest gaps in all three components of capital spending are in Ireland, Iceland, and Greece, where pre-crisis imbalances were very large. There 


\section{ECO/WKP(2014)64}

are only a few economies, most notably Canada and Norway, in which all three investment rates are above the pre-crisis period.

Figure 2. Investment is low relative to pre-crisis averages in many OECD countries

Distribution of investment gaps by type of investment

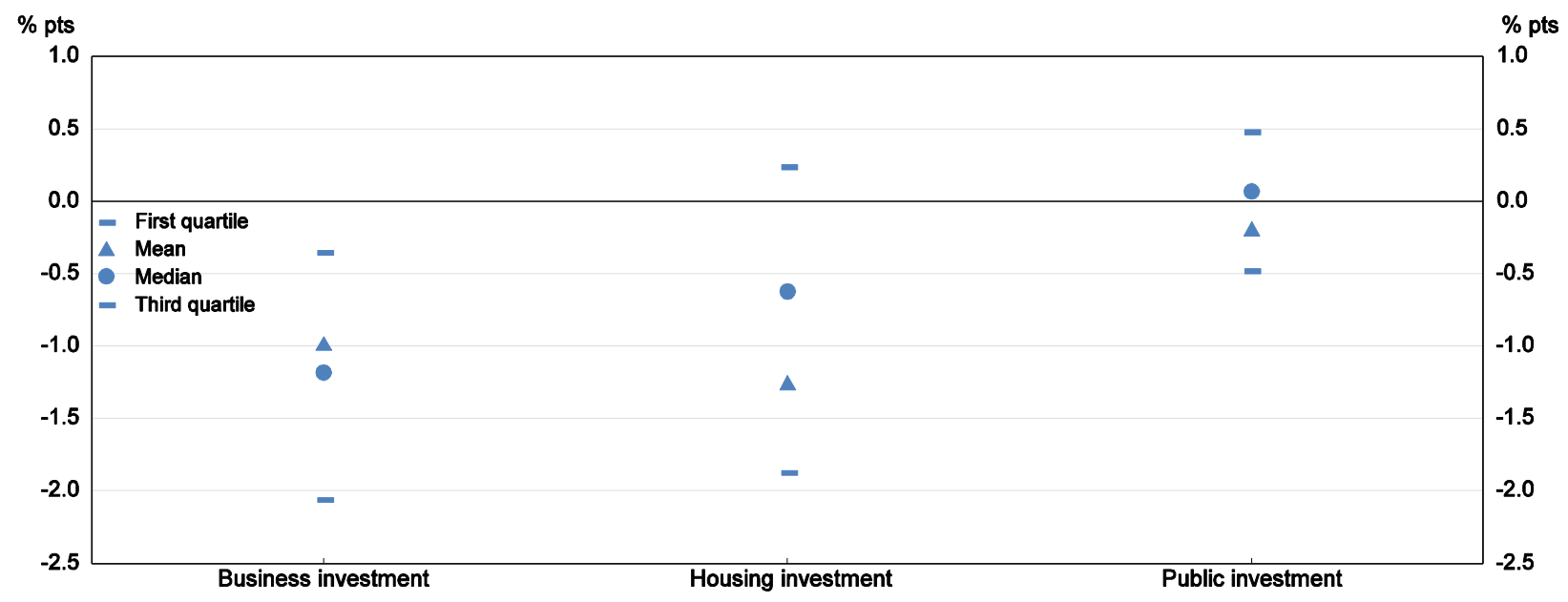

Note: Investment gaps are calculated as the difference between the investment ratio in 2013 and the 1996-2007 average for OECD countries for which a breakdown of investment is available. All statistics shown are unweighted.

Source: OECD Economic Outlook database; and OECD calculations.

9. The recent and widespread sluggishness in business investment in real, as well as nominal, terms has raised concerns about the strength of the recovery from the crisis, in part because of the direct impact of weak investment on potential output growth and, indirectly, on global trade growth. Business investment fell by 20 per cent in real terms in the recent crisis - more than double the fall seen in other post-war recessions (Figure 3, left panel). And while the initial recovery was fairly strong, and faster than GDP growth as would be expected, investment barely grew at the same pace as GDP in 2012 and 2013 (Figure 3, right panel). 
ECO/WKP(2014)64

Figure 3. Real business investment growth has been weak compared to previous cycles

Peak in OECD real investment $=100$

Level (Chained volumes)

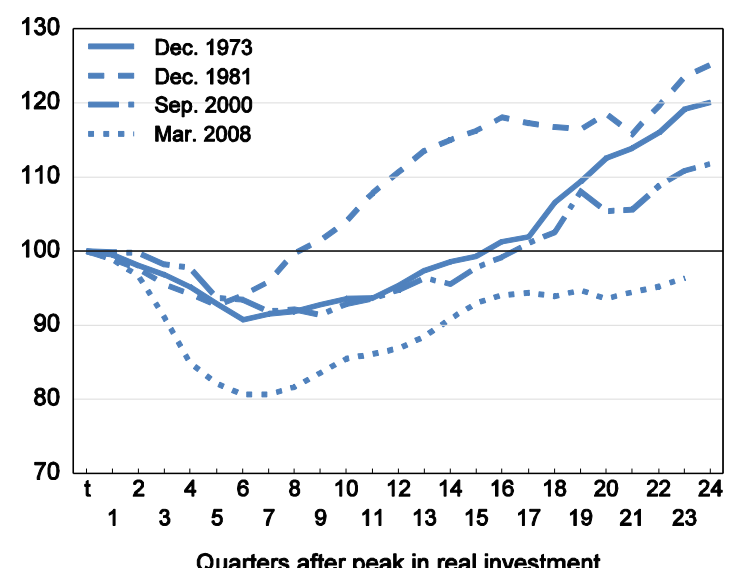

Ratio of real investment to GDP

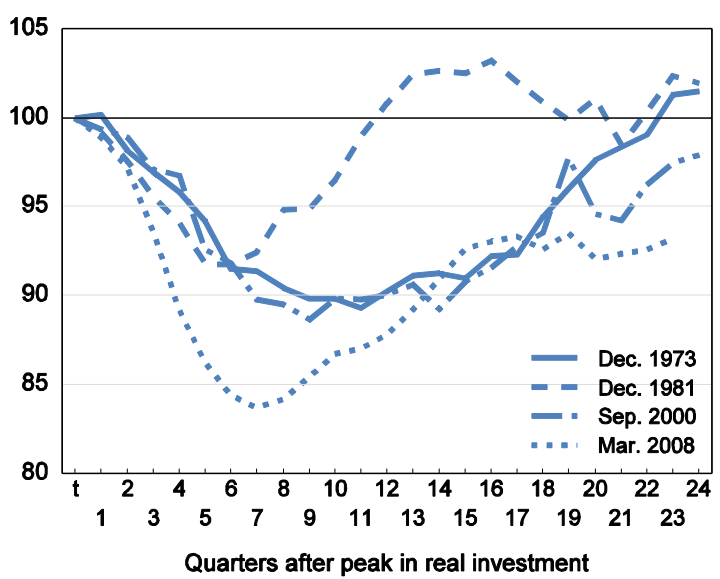

Note: Data are for OECD countries for which the breakdown of investment is available.

Source: OECD Economic Outlook database; and Authors' calculations.

10. One argument against the use of pre-crisis averages to assess investment gaps is that potential output growth rates are now very different in some countries, reflecting factors such as slower labour force growth due to population ageing. Some of these factors were already anticipated before the crisis began (OECD, 2008), but the crisis itself is also estimated to have reduced OECD-wide potential output in 2014 by $2 \frac{1}{4}-3 \frac{1}{4}$ per cent $(\mathrm{OECD}, 2014 \mathrm{a})$. These developments are likely to influence the dynamism of investment and potentially the steady-state capital output ratio. ${ }^{2}$ Population ageing might also hamper investment in some countries by diminishing saving rates. However, increasing depreciation rates, reflecting the changing composition of capital goods, as well as the increasing age of existing capital goods through the crisis could offset some or all of these effects. ${ }^{3}$ Thus, an alternative approach is to look at measures of the gap between current investment rates and estimated steady-state investment rates, since this allows the range of different forces set out above to be taken into account.

11. An estimate of the steady-state investment-to-output ratio can be derived using inputs from the OECD long-term growth projections (OECD, 2014a). In many OECD countries, investment-output ratios are not only well below pre-crisis levels but also well below likely future steady-state levels when output gaps are closed (Box 1). Although there are large differences across OECD economies, the steady-state ratio in most economies is likely to be above the 2013 ratio, with several economies having large investment gaps, including the vulnerable euro area economies. If capital depreciation rates or potential output growth rates were higher, or if the steady-state capital-output ratios were to be reached faster than assumed, the current investment gaps would be even larger.

2. Moreover, in some countries, nominal fixed investment has been on a downward trend relative to GDP since the early 1970s.

3. The average age of the current-cost fixed assets held by non-financial corporates in the United States is estimated to have risen from 14.7 years in 2007 to 15.4 years in 2012, with the latter being the highest level since 1967. 


\section{Box 1. Investment gaps are presently large}

An indication of the difference between current investment levels and longer-term needs can be obtained by estimating a steady-state investment-to-output ratio using inputs from the OECD long-term growth projections (OECD, 2014a). From around 2020 onwards in the long-term database, the constant-price capital-output ratio moves around a long-run level according to changes in the real cost of capital, with output gaps generally closed from this point. Assuming that an equilibrium ratio is attained at a particular point in time, the capital-output ratio, the depreciation rate and the growth rate of potential output in the long-term baseline can be used to calculate an approximation of the steady-state investment-to-output ratio that is required to achieve this.

The steady-state level of investment to (potential) output is given by: $i^{*}=\frac{k^{*}(g+\delta)}{(1+g)}$, where $\mathrm{k}^{*}$ is the steady-state capital-output ratio, $\delta$ is the depreciation rate which is assumed constant over time, and $\mathrm{g}$ is the endogenous potential growth rate, which is dependent upon labour utilisation, physical and human capital intensity and multi-factor productivity. In the calculations below, $k^{*}$ is set at the ratio of (non-residential) capital to trend output in 2025 in the OECD's long-term baseline scenario, by which time current trends in capital intensity have generally stabilised but is not so distant that new forces pushing up the cost of capital have taken hold. Steady-state values for $g$ and $\delta$ are approximated by the average over 2020-2025. The calculations are only illustrative, since the growth rate of potential output and the user cost of capital, and hence the implied steady state capital-output and investment-output ratios, fluctuate through the long-term baseline (which runs up to 2060).

In most OECD economies, investment ratios in 2013 are below the illustrative steady-state level, with a gap of 2 percentage points or more in one third (see figure below). But there is a fairly large range, with the current investment ratio above this implicit longer-term level in some countries. ${ }^{4}$

The assumptions made about the steady-state capital ratio, depreciation rate and potential growth rate of output will all affect the steady-state investment ratio, and the catch-up in investment needed to reach the steady-state capital output ratio. For instance, a continuation of the past steady upward trend in the depreciation rate, reflecting the change in the mix of capital goods, would raise the steady-state level of investment required to maintain the capital stock. Alternatively, trend output growth could be stronger than in the baseline if additional growth-enhancing structural reforms are undertaken.

A simple way of illustrating the impact of these effects on the steady-state investment ratio is to add $1 / 2$ percentage point to both the depreciation rate and the potential growth rate. The average effect of these two changes, for a given steady-state capital-output ratio, (shown in the figure below) is to raise the required steady-state investment ratio by almost $2 \frac{1}{4}$ percentage points (unweighted), with the largest effect in Japan (adding 31/2 percentage points to the required ratio). The higher depreciation rate and stronger potential output growth each account for around one-half of these additional effects.

An important caveat to this exercise is that changes in potential output growth could change the steady-state capital-output ratio both indirectly, and directly by raising the equilibrium real interest rate in proportion to the rise in the potential growth rate.

4. In several countries, the data are on a 2008 System of National Accounts basis, which incorporates a broader definition of investment. 


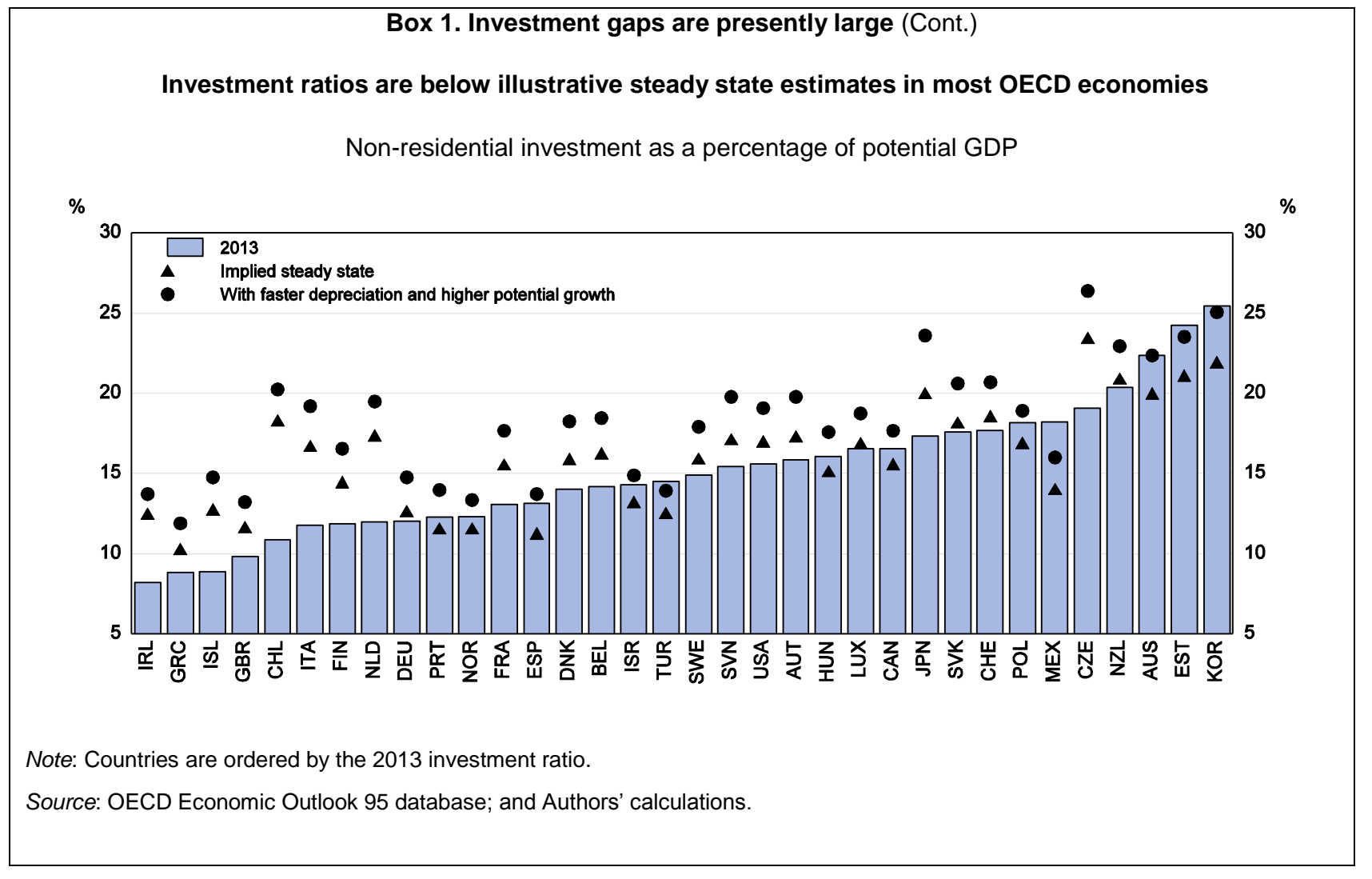

\section{3. $\quad$ Forces affecting business investment}

12. This section reviews the potential determinants of business fixed investment, the largest component of total investment, and assesses the extent to which they have been acting to constrain investment growth since the start of the crisis. The initial focus is on output growth and the user cost of capital, two of the principal determinants of investment in many empirical models. ${ }^{5}$

\section{Output growth}

13. With the accelerator mechanism typically found to have a key role in explaining short-term swings in investment (Chirinko, 1993), the modest pace of the recovery from the crisis has clearly been one factor constraining investment growth in recent years. Survey evidence clearly points to the significant constraints that weak demand conditions have placed on production and investment in the past two years (Figures 4 and 5), especially in the euro area.

5. In a standard neo-classical model, the long-run demands for capital and labour can be derived from a production function using the first-order conditions that the marginal product of each input should equal its (mark-up adjusted) real price. This points to key determinants of the equilibrium level of capital (or equivalently investment (Bean, 1981)): the level of output and the user cost of capital, with the respective coefficients depending on returns to scale and the elasticity of substitution between labour and capital. With a Cobb-Douglas production function, as used in the OECD supply-side framework, both long-run coefficients will be unity. Given the significant lags involved in adjusting investment, it is possible to obtain a model in which capital demand (investment) depends upon output growth (the "accelerator" mechanism), changes in the user cost of capital and also the long-run equilibrium determinants. 
Figure 4. Demand has constrained production

Share of firms reporting that demand is limiting production

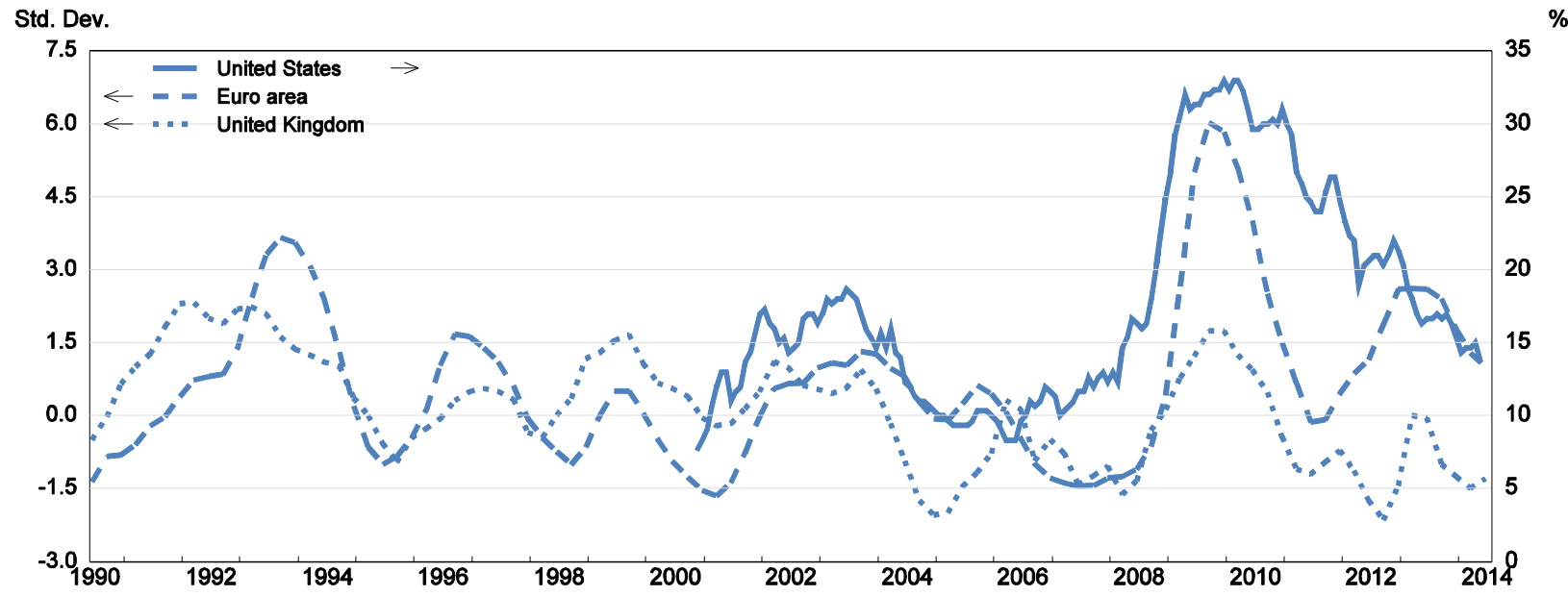

Note: Euro area and UK data cover manufacturing firms only. To improve comparability, euro area and UK data are normalised over 1996-2007 and smoothed with a 2-quarter moving average. US data are from the NFIB survey and are a 3-month moving average of the share.

Source: Datastream; European Commission; and Authors' calculations.

14. A simple benchmark model of investment growth also illustrates the extent to which cyclical fluctuations in output can account for a considerable part of the observed behaviour of investment since the onset of the crisis. Estimates for a handful of countries, using simple equations relating investment growth to past investment growth and current and lagged output growth, are shown in Figure 6. The findings differ across the economies shown, but in general highlight two key points: the downturn in investment growth at the height of the crisis was typically larger than can be accounted for on the basis of past relationships with output growth; and the growth of business investment between mid-2011 and mid-2013 was weaker than might have been expected given output developments at that time. Related findings are obtained by Pinto and Tevlin (2014). The broader empirical model across 13 economies, set out in Appendix 1, suggests that the decline in output can account for a sizeable proportion of the drop in investment in the early stages of the recession. The large negative output gap that has developed since the start of the crisis (a proxy for capacity utilisation) has subsequently weighed heavily on investment, especially in the United States, France and the United Kingdom. 
Figure 5. Demand is limiting investment in the euro area

Balance of firms reporting that demand is limiting investment; in standard deviations

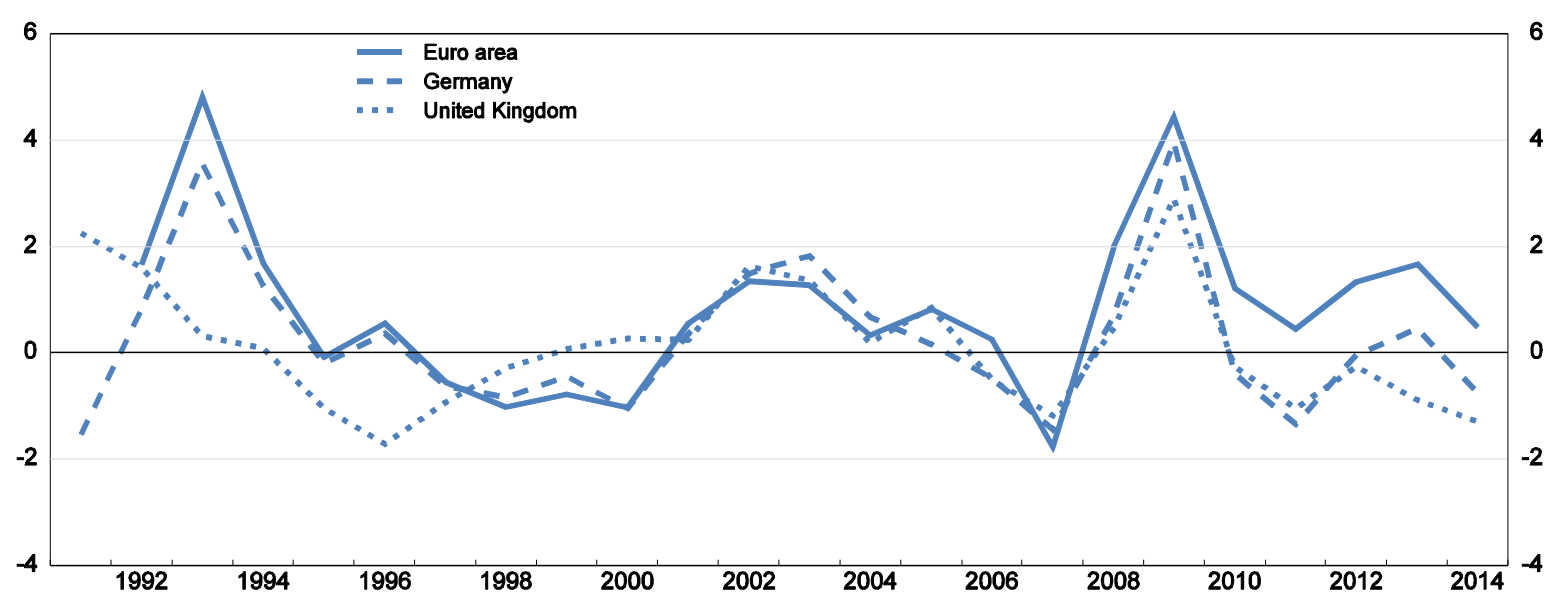

Note: Data are for manufacturing firms and are normalised over 1996-2007.

Source: European Commission; and Authors' calculations.

\section{The user cost of capital}

15. The real user cost of capital typically depends on the relative purchase price of a unit of capital, the real post-tax financial cost of capital, the depreciation rate of capital and assorted provisions of tax systems, such as investment tax credits and depreciation allowances. ${ }^{6}$ A representative measure of the real user cost of capital is shown in Figure 7, derived using the following formula:

$$
U C C=\frac{P^{K}}{P^{Y}}(\theta(1-\tau) i+(1-\theta) i-\pi+\delta)\left(\frac{1}{1-E M T R}\right) ;
$$

where $P^{K} / P^{Y}$ is the relative price of business investment to GDP; $\theta$ is the fraction of debt in corporate liabilities (using the 1999-2013 average); $\tau$ is the statutory corporate tax rate; $i$ is the long-term government bond rate (i.e. abstracting from the differences between business and government borrowing rates); $\pi$ is the change in the GDP deflator; $\delta$ is the depreciation rate on the business and public capital stock; and EMTR is the effective marginal tax rate obtained from the Oxford University Centre for Business Taxation (CBT) Tax Database which allows for the deductibility of depreciation expenses, though not investment tax credits. $^{7}$

6. This can be derived using a Hall-Jorgenson rental rate formula for the cost of a unit of capital services.

7. The EMTR is based on a number of assumptions, but the tax wedge as measured here is very close to a measure calculated as $(1-\tau Z) /(1-\tau)$, where $Z$ is the present value of depreciation allowances for an additional dollar of investment (weighted across investment goods) available from the Institute for Fiscal Studies database which ends in 2005. These data are used to backcast the tax wedge in those countries in which the CBT Tax Database does not have complete coverage over the sample period shown. 
Figure 6. A simple accelerator model of growth in business investment

$\%$

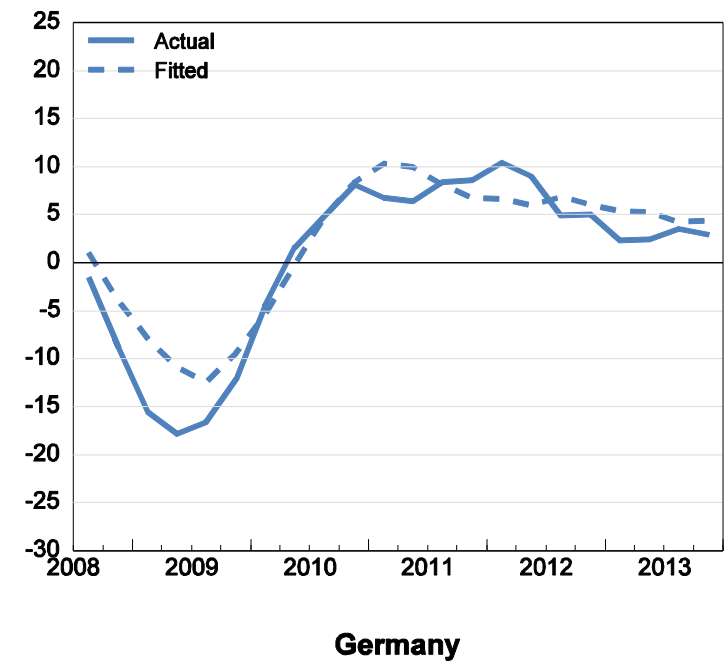

$\%$

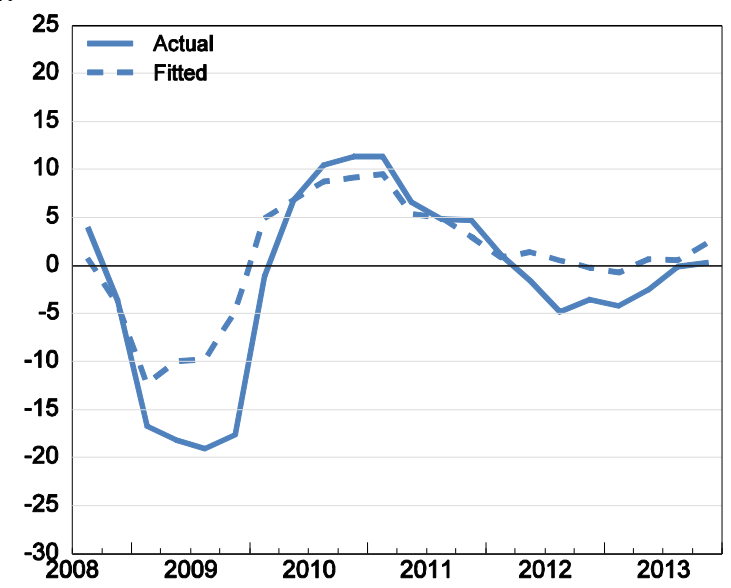

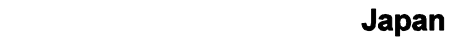

$\%$

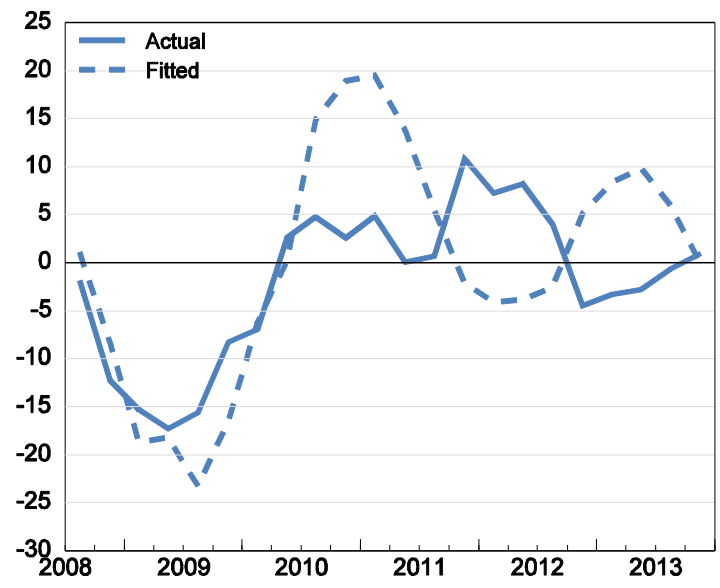

France

$\%$

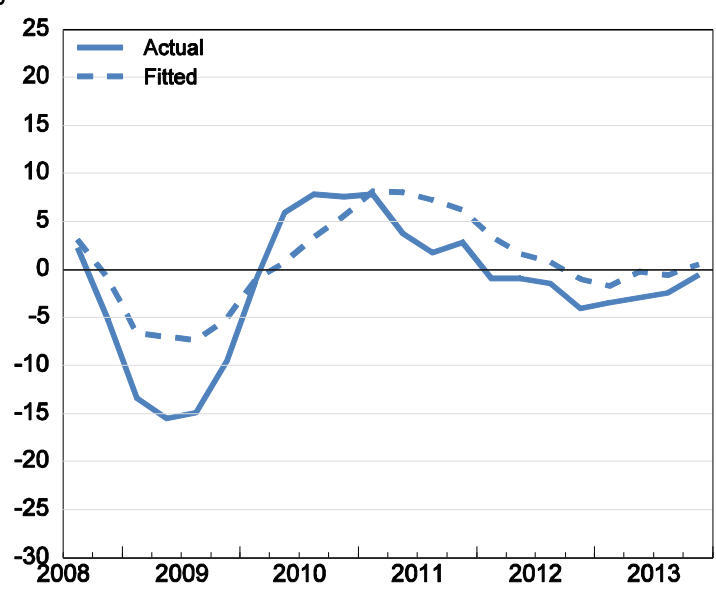

Note: The dependent variable is the annual growth rate in real business investment. The model is estimated on quarterly data from 1980Q1 to 2008Q2 using up to 8 lags of the dependent variable and the annual growth rate of real GDP. All lags up to the highest significant lag are retained. The dynamic forecast from the model is produced for the period 2008Q3 to 2013Q4 ('Fitted') and graphed together with the annual growth rate of real business investment ('Actual').

Source: OECD Economic Outlook database; and Authors' calculations. 
Figure 7. User cost of capital

Weighted average of $\mathrm{G} 7$ countries, real

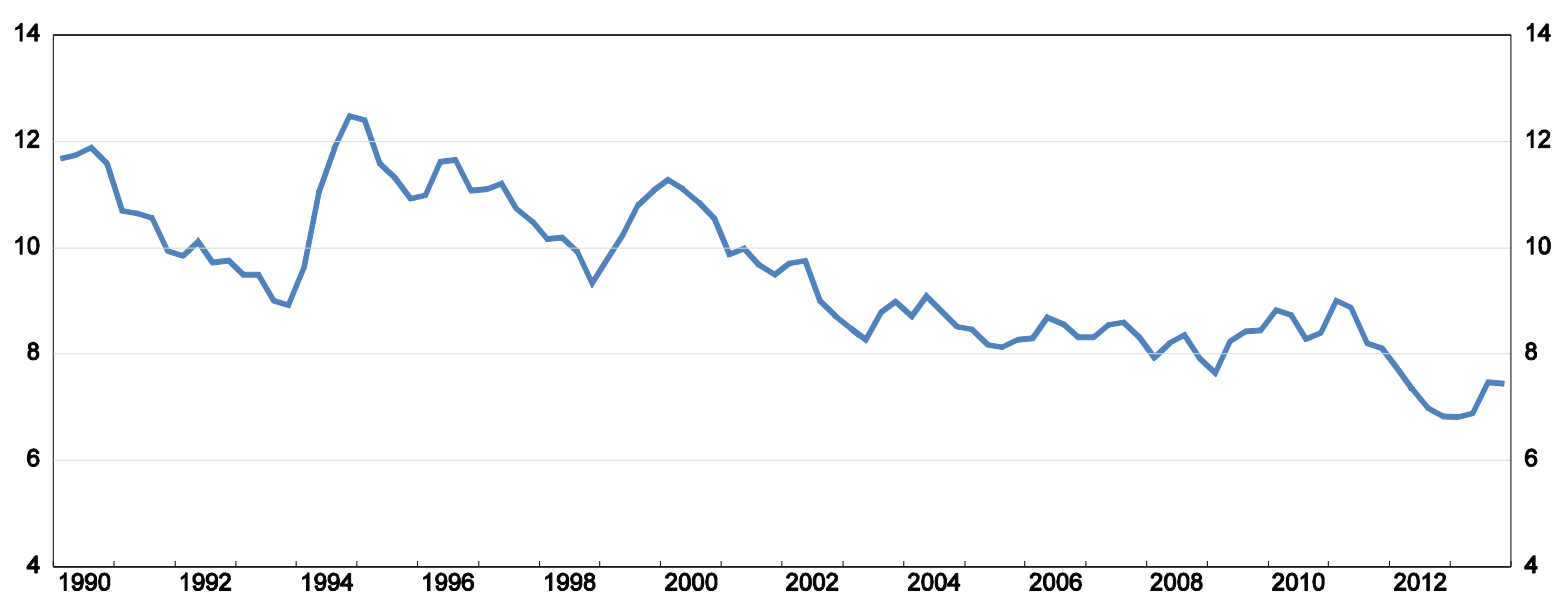

Source: Authors' calculations.

16. Three key influences stand out. First, the long-term decline in the relative price of investment goods, largely reflecting ICT-related quality improvements, appears to have slowed sharply from around 2005 onwards (Figure 8, left panel). All else equal, this might have lowered the growth of investment demand. Second, the tax wedge has gradually drifted down over time (Figure 8, left panel). Third, after increasing by around 1 percentage point over 2009-2010, the user cost of capital has subsequently fallen sharply to be below its level in the pre-crisis years due to a fall in the financing term (Figure 8, right panel). If corporate bond yields are used as a proxy for the marginal rate of finance rather than government rates, the rise in the user cost of capital in 2009 becomes sharper. However, the fall over the past two years is similar, with the cost of capital declining towards its level prior to the crisis. ${ }^{8}$ Thus the cost of capital may now be less of a constraint on investment growth, at least for large companies that can access funds at interest rates close to those at which the government can borrow.

8. This is based on the yields from a 5-10 year corporate bond index in most countries. The analysis abstracts from the difference between the cost of debt and equity: the cost of equity capital is typically higher (reflecting a higher risk premium). In recent years there have been marked differences between the United States, where the cost of equity has risen, and the euro area, where the cost of equity has declined (Blundell-Wignall \& Roulet, 2014; ECB, 2013). 
Figure 8. Components of the user cost of capital

Weighted average of $\mathrm{G} 7$ countries

A. Relative price of investment goods and tax wedge

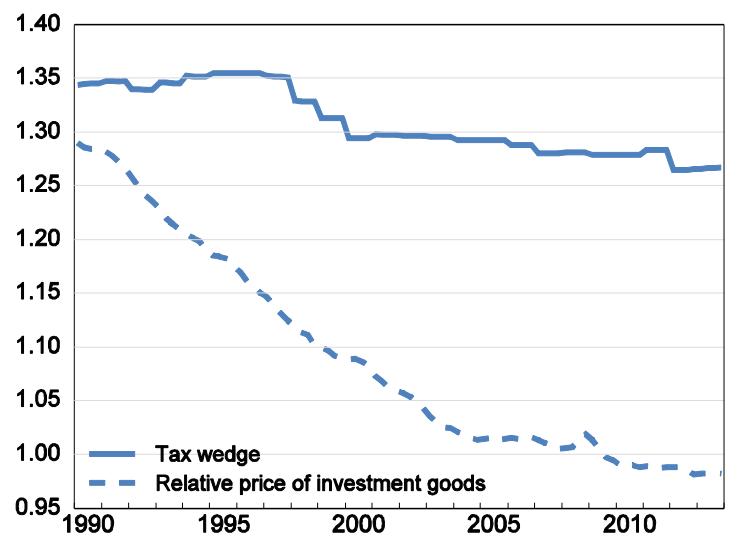

B. Financing term

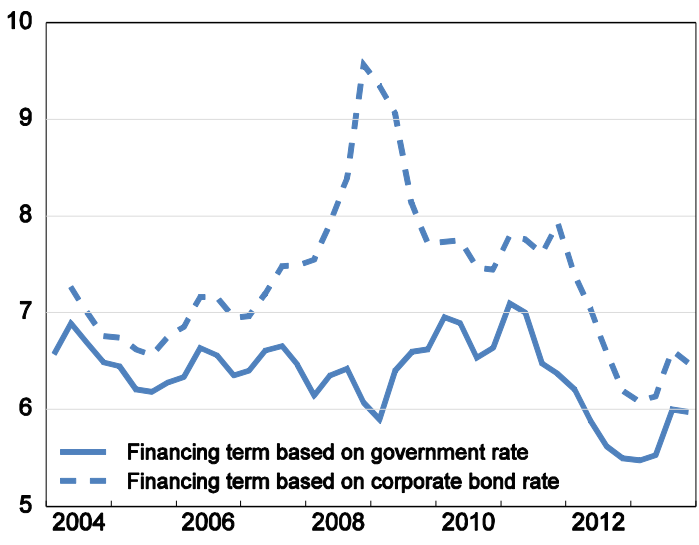

Note: The financing term incorporates the tax deductibility of debt interest payments and is inflation-adjusted.

Source: Authors' calculations.

17. While the relative price of investment goods is reasonably well measured, the proxies for the tax wedge and borrowing costs are more difficult to measure and may vary considerably across countries. Empirical evidence suggests that reducing the statutory tax rate should increase investment, but with differences across firm type (OECD, 2010). ${ }^{9}$ Over half of the OECD countries have reduced statutory tax rates since 2007. However, simple correlations between the investment gap and change in the corporate tax rate or effective marginal tax rate do not reveal a negative relationship, even though the largest tax reductions occurred in countries that had the highest rates (and should therefore have larger investment responses). It may be that the direct aggregate impact of these tax changes has been limited by low profitability. Nonetheless, by improving internal cash-flow, these tax reductions could have helped some firms survive that might otherwise have gone out of business. Some countries have also introduced temporary tax credits or strengthened investment allowances for a fixed period since the crisis began, which may also have affected investment at the margin. ${ }^{10}$

18. The user cost of capital is likely to be higher than shown, and possibly substantially higher, in some countries due to the constraints on credit supply arising from weak or impaired banking systems. ${ }^{11}$ This 'credit channel' is likely to affect small firms in particular, since it is these firms that are more likely to be dependent on this source of funding at the margin. The spread between average bank loan rates (over a mix of maturities) and government bonds has risen since the immediate pre-crisis period in all of the major economies, ${ }^{12}$ with the exception of Japan, and bank lending standards have also tightened,

9. See Box B.5: "Empirical evidence on the effect of taxes on investment" in OECD (2010) for a more detailed summary of empirical findings.

10. Temporary tax credits will not be reflected in the measure of the user cost of capital set out above.

11. Estimates by Cournède (2010) suggest that if the user cost of capital were to return to the average levels over 1991-2001, reflecting a durably higher risk premium after the crisis, the equilibrium level of the capital stock could be lowered by around $7 \%$.

12. As noted above, this is an imperfect proxy for the marginal cost of new funds. 
especially in the euro area, although this process now seems to be ending (Figure 9). This suggests that, in the euro area at least, the weak state of the banking system could be an important factor restraining investment at present, especially for SMEs (ECB, 2013).

Figure 9. Bank lending rates have declined, but spreads have risen
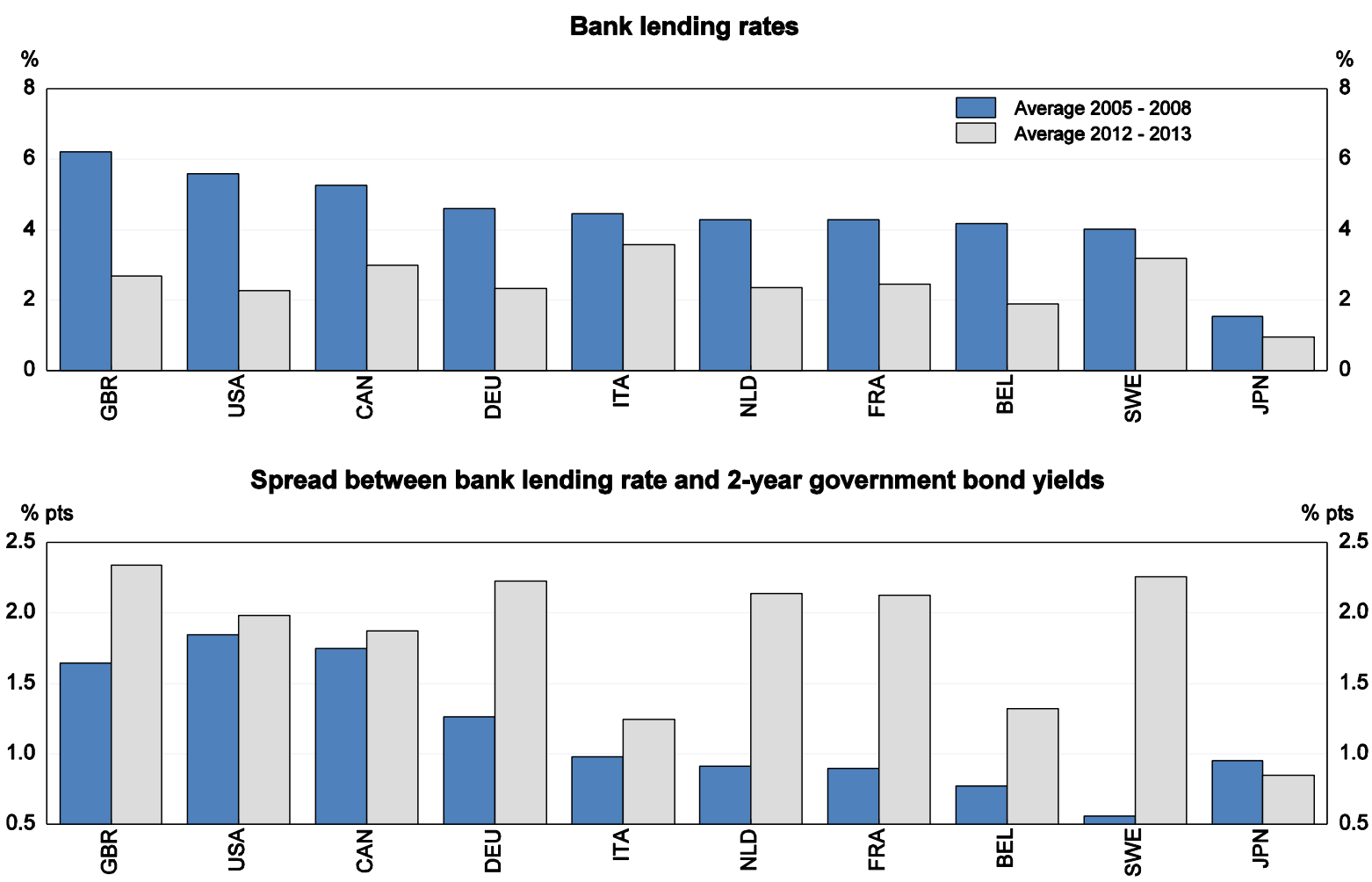

Note: Weighted average across all maturities. Average maturities may differ across countries. Data are lending rates (all maturities) for loans to non-financial corporations for the United States, rates for new loans to non-financial corporations and averages across member countries for the euro area, rates for new loans to non-financial corporations and households for Japan, rates for new loans to non-financial corporations for the United Kingdom, rates for new prime loans to non-financial corporations for Canada, rates for new loans to non-financial corporations for Sweden.

Source: Bank of England; Bank of Japan; Datastream; European Central Bank; Riksbanken; US Federal Reserve; and Authors' calculations. 
Figure 10. Credit standards tightened significantly in 2008-09

Net percentage of banks tightening standards
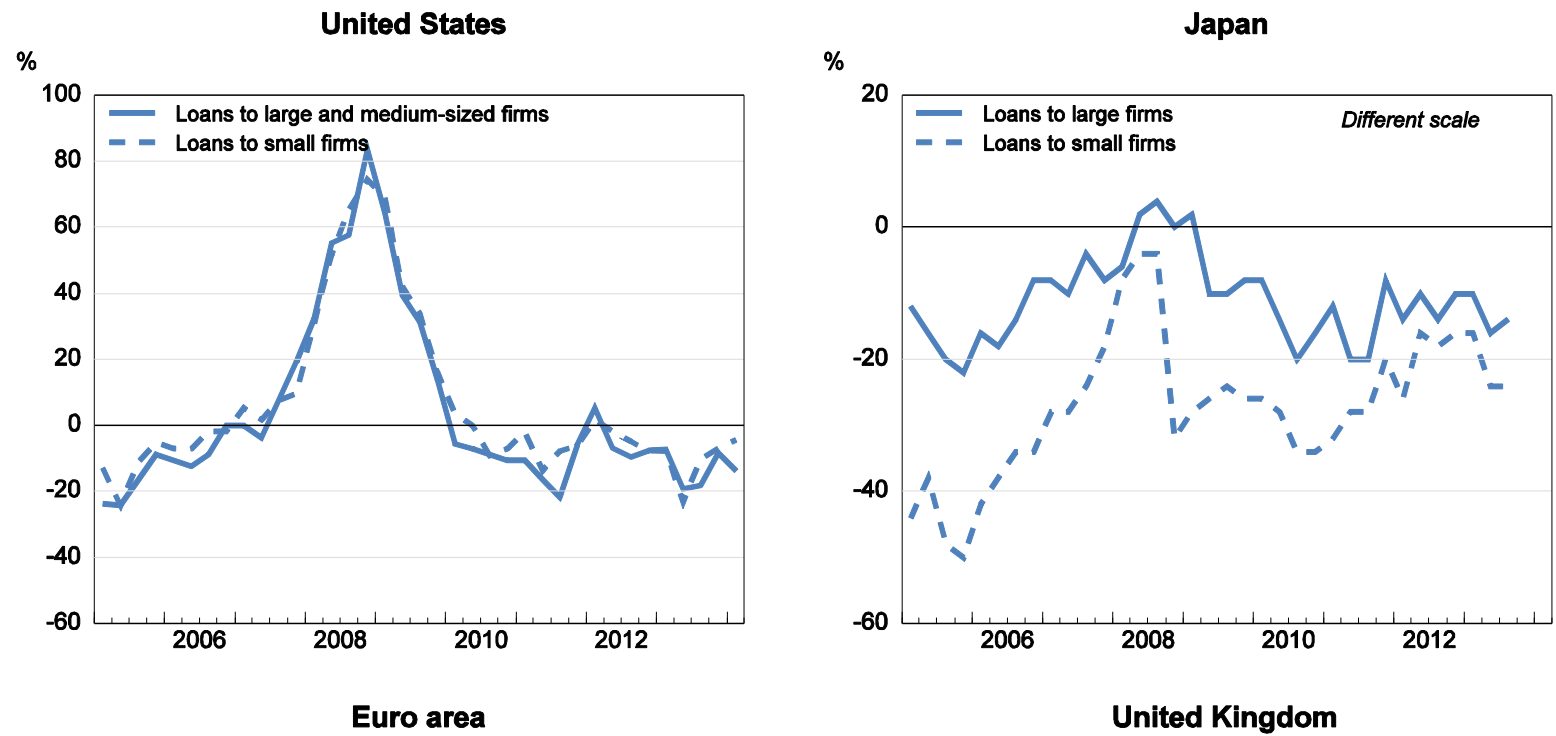

$\%$

Euro area

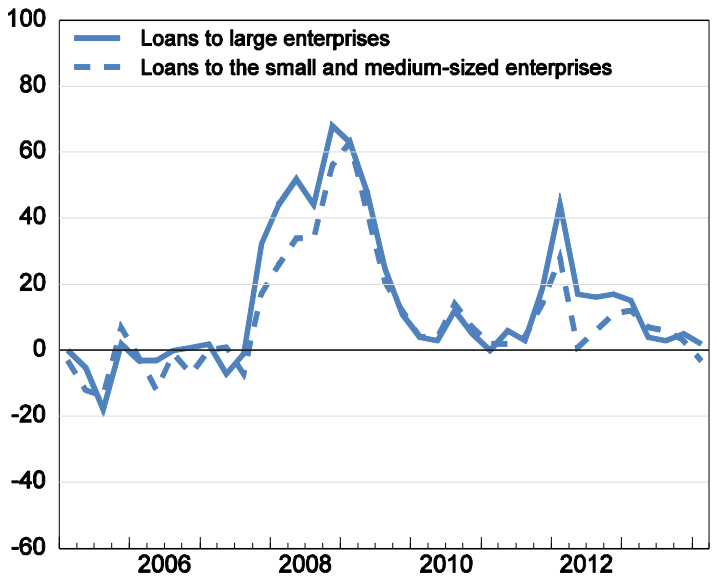

$\%$

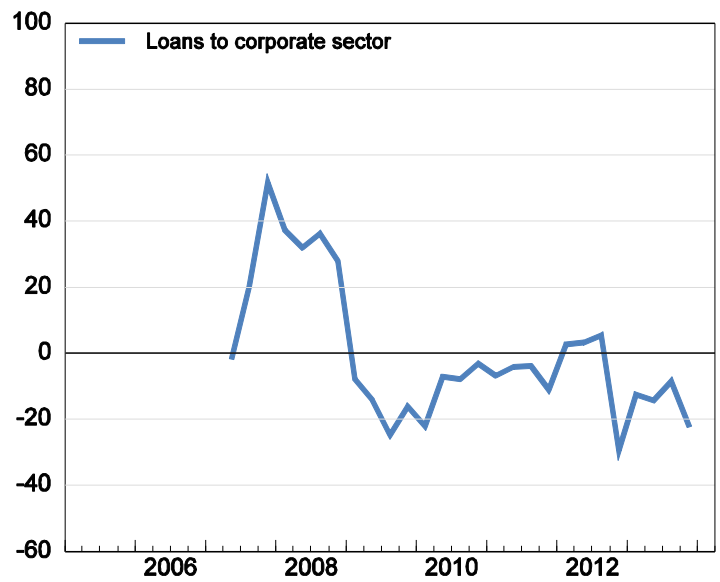

Note: Positive numbers indicate credit availability contracting and negative numbers indicate credit loosening.

Source: Bank of England; Bank of Japan; European Central Bank; and US Federal Reserve.

\section{Corporate balance sheet and income developments}

19. The structure of corporate balance sheets influences the extent to which factors such as information asymmetries (between lenders and firms), agency problems and potential bankruptcy costs affect investment decisions, and also the extent to which credit restrictions are a binding constraint. Higher debt servicing payments, higher leverage and reduced cash flow all raise the premium that firms have to pay for external finance, and also leave them more exposed to economic shocks, such as large adverse changes in demand or in financial market conditions. Subsequent balance sheet adjustment and deleveraging could then result in reduced levels of investment, as well as higher corporate gross savings. This is borne out by empirical evidence (Benito and Young, 2007; Ruscher and Wolff, 2012), which suggests that higher leverage and lower corporate liquidity both raise the likelihood of balance sheet 
adjustment and reductions in corporate expenditure, including on fixed investment. Such effects can persist for some time until leverage is reduced and liquidity improved.

20. Key balance sheet developments across a number of OECD economies and the aggregate euro area are summarised in Table 2, revealing the marked differences in the composition of non-financial corporate balance sheets across economies. Three important features stand out:

- As the crisis got underway in 2008 , debt leverage (expressed relative to equity) was at relatively high levels in all economies. This contributed to the large reductions in investment volumes at the height of the crisis. However, non-financial corporate leverage has subsequently declined considerably, and in the United States, Japan and the aggregate euro area is now at or below precrisis norms. Consequently, this source of balance sheet pressure is unlikely to be acting as a significant restraint on investment levels in these economies. Italy and Portugal are clear exceptions, with debt leverage currently well above the levels entering the crisis. Leverage has also remained at high levels in Australia.

- It also appears unlikely that the second source of possible adverse balance sheet developments, corporate liquidity, is a significant check on corporate expenditure at the present time. In almost all of the G7 economies, as well as Australia and Korea, the post-crisis share of financial assets held as currency and deposits by non-financial enterprises is presently above longer-term norms. These higher levels of liquidity suggest that there is little need for further corporate balance sheet adjustment in these economies, since higher cash and deposit holdings provide firms with a buffer against adverse shocks and a means of financing additional expenditure, including investment, from internal resources. They also imply that large companies may now have only a limited need for external finance for new investment projects. ${ }^{13}$ However, to the extent that the build-up in cash holdings reflects precautionary motives arising from continued uncertainty about demand and external financing conditions (Bates et al., 2009; Sanchez and Yurdagul, 2013), the feed-through of improved liquidity into investment and other forms of corporate expenditure could take some time to emerge.

- A third balance sheet development in some economies since the onset of the financial crisis has been a rise in the share of non-equity securities in total debt. This development has been especially pronounced in the United States, France, the United Kingdom and Norway, where the share of total debt accounted for by corporate bonds has risen sharply in recent years. In contrast, only small changes have occurred in Japan and Germany, where external finance has historically been largely credit-based. In the context of the current low levels of long-term interest rates and weak banking systems, additional corporate bond issuance has provided a means for companies in all the major countries to raise additional financing at a relatively low cost (Figure 11). This should support corporate expenditure, potentially including investment. ${ }^{14}$ However, the low cost of debt relative to equity also creates an incentive for companies to borrow to return funds to shareholders, through buybacks and dividends (Blundell-Wignall and Roulet, 2014).

13. The present levels of corporate liquidity imply that many forms of corporate expenditure, including mergers and acquisitions, fixed investment and dividends, could rise substantially as uncertainty eases and private demand strengthens. For example, the reductions in holdings of currency and deposits that would occur if the 2013 share of currency and deposits in total financial assets returned to the average level over 1999-2007 are equivalent to a little over one-third of the 2013 level of business investment in Japan and Germany, and around one-tenth in the United States.

14. The source of financing also affects the type of investment: risky investment in innovation is more typically financed by equity rather than debt (Andrews and Criscuolo, 2013). 
Table 2. Significant changes have occurred in non-financial corporate balance sheets since the crisis began

\begin{tabular}{|c|c|c|c|c|c|c|c|c|}
\hline & Canada & Euro area & France & Germany & Italy & Japan & $\begin{array}{c}\text { United } \\
\text { Kingdom }\end{array}$ & $\begin{array}{l}\text { United } \\
\text { States }\end{array}$ \\
\hline \multicolumn{9}{|l|}{ Debt-to-equity ratio } \\
\hline Average 99Q1 - 07Q4 & 0.87 & 0.92 & 0.66 & 1.31 & 1.06 & 1.70 & 0.63 & 0.63 \\
\hline 2008Q4 & 1.09 & 1.15 & 0.87 & 1.60 & 1.15 & 2.06 & 0.99 & 0.86 \\
\hline $2013 Q 3$ & 0.96 & 0.92 & 0.67 & 1.20 & 1.36 & 1.29 & 0.71 & 0.59 \\
\hline \multicolumn{9}{|c|}{ Share of cash and deposits in total assets (\%) } \\
\hline Average 99Q1 - 07Q4 & 15.2 & 9.6 & 4.9 & 11.4 & 12.3 & 23.4 & 22.2 & 8.9 \\
\hline $2008 \mathrm{Q} 4$ & 20.7 & 11.2 & 6.7 & 13.7 & 15.1 & 24.5 & 21.6 & 7.8 \\
\hline $2013 Q 3$ & 20.2 & 11.6 & 8.4 & 14.4 & 17.4 & 25.7 & 26.0 & 10.2 \\
\hline \multicolumn{9}{|c|}{ Share of non-equity securities in debt (\%) } \\
\hline Average 99Q1 - 07Q4 & 24.0 & 6.0 & 13.7 & 3.8 & 3.1 & 12.5 & 21.9 & 26.3 \\
\hline 2008Q4 & 18.2 & 5.3 & 10.5 & 5.0 & 3.3 & 10.8 & 17.1 & 26.5 \\
\hline \multirow[t]{2}{*}{$2013 Q 3$} & 20.3 & 8.1 & 16.2 & 5.1 & 7.0 & 11.3 & 24.7 & 38.4 \\
\hline & Australia & Belgium & Denmark & Korea & Norway & Portugal & Spain & Sweden \\
\hline \multicolumn{9}{|l|}{ Debt-to-equity ratio } \\
\hline Average 99Q1 - $07 \mathrm{Q7}$ & 0.70 & 0.65 & 0.63 & 2.04 & 1.40 & 1.04 & 1.00 & 0.79 \\
\hline 2008Q4 & 0.97 & 0.67 & 0.88 & 2.37 & 1.82 & 1.16 & 1.40 & 1.02 \\
\hline $2013 Q 3$ & 0.95 & 0.51 & 0.57 & 1.94 & 1.60 & 1.28 & 1.05 & 0.64 \\
\hline \multicolumn{9}{|c|}{ Share of cash and deposits in total assets (\%) } \\
\hline Average 99Q1 - 07Q4 & 34.7 & 8.8 & 8.8 & 24.9 & 29.8 & 11.5 & 10.8 & 6.2 \\
\hline $2008 Q 4$ & 39.8 & 7.5 & 8.7 & 26.6 & 29.3 & 10.5 & 11.8 & 7.3 \\
\hline $2013 Q 3$ & 43.1 & 6.7 & 4.7 & 27.0 & 25.0 & 9.9 & 11.7 & 6.2 \\
\hline \multicolumn{9}{|c|}{ Share of non-equity securities in debt (\%) } \\
\hline Average 99Q1 - 07Q4 & 25.4 & 3.8 & 7.0 & 22.1 & 13.7 & 6.8 & 1.5 & 7.1 \\
\hline $2008 Q 4$ & 21.9 & 3.4 & 4.2 & 15.6 & 9.5 & 9.7 & 0.7 & 7.4 \\
\hline $2013 Q 3$ & 22.5 & 5.6 & 7.0 & 17.6 & 14.2 & 12.0 & 1.2 & 9.2 \\
\hline
\end{tabular}

Note: Non-equity securities include short- and long-term securities.

Source: Bank of Japan; OECD Financial Accounts database; and Authors' calculations. 
Figure 11. Non-financial corporations' gross bond issuance has risen recently Issuance as a per cent of GDP

United States

$\%$

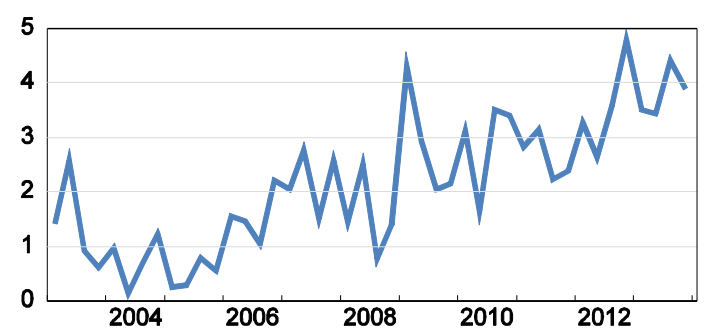

Euro area

$\%$

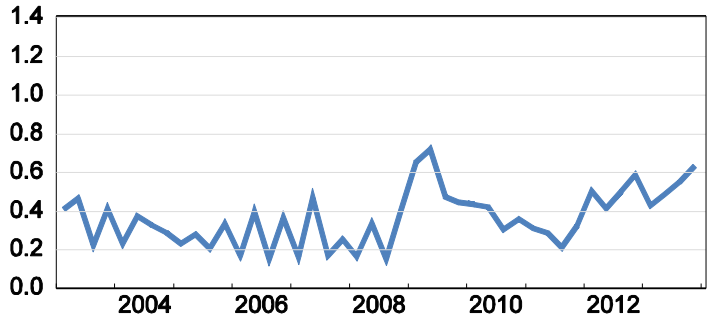

Canada

$\%$

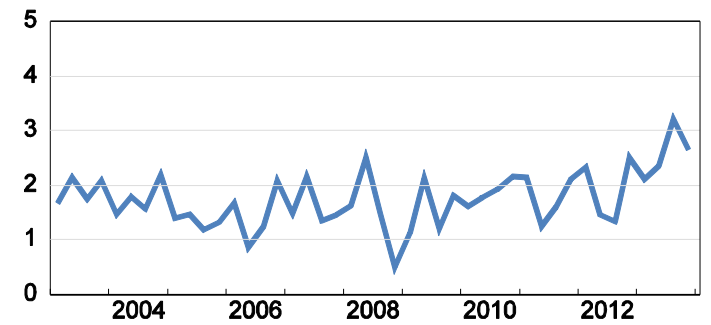

Japan

$\%$

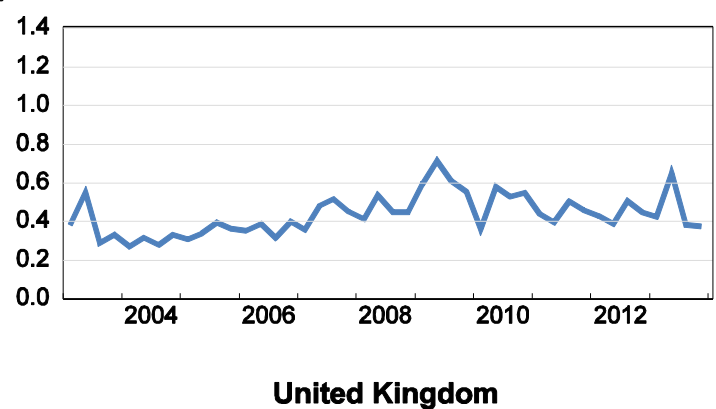

$\%$

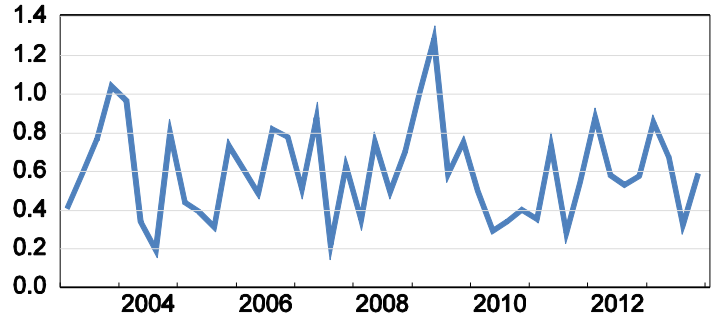

Note: Gross bond issuance of private non-financial corporations in national and foreign currencies. Issuance covers publicly-offered private bonds for Japan, long-term securities other than shares at nominal value for the euro area, and corporate bond liabilities from the flow of funds for the United States.

Source: Bank of England; European Central Bank; Japan Securities Dealers Association; US Federal Reserve; and OECD Economic Outlook database.

21. The availability of internal finance through profitability and cash flow can also affect investment through similar channels as those set out above (Bond et al., 2003). Weaker cash flow can exacerbate the need for external finance, and also affect the ability of a firm to borrow and the cost of credit. Low liquidity can also increase the vulnerability of firms to external shocks, thereby increasing the motivation for precautionary saving.

22. The available data suggest that overall, real corporate profits (financial and non-financial enterprises) rose by an average of 1 per cent per annum in the past three years, compared to a four-decade average of 3 per cent (Figure 12). However, there is considerable variation across countries, with profit 
growth remaining comparatively solid in the United States, but barely changing at all in real terms in the euro area. In most countries, quarterly data suggest that profitability picked up during 2013, improving the conditions for investment. Evidence from a number of different corporate surveys also suggests that the constraints imposed by adverse financial conditions during the crisis have now faded to pre-crisis levels in most economies, although not in the euro area (Figure 13).

Figure 12. Growth in real corporate profits has been solid in the United States but weaker elsewhere

Annual percentage changes
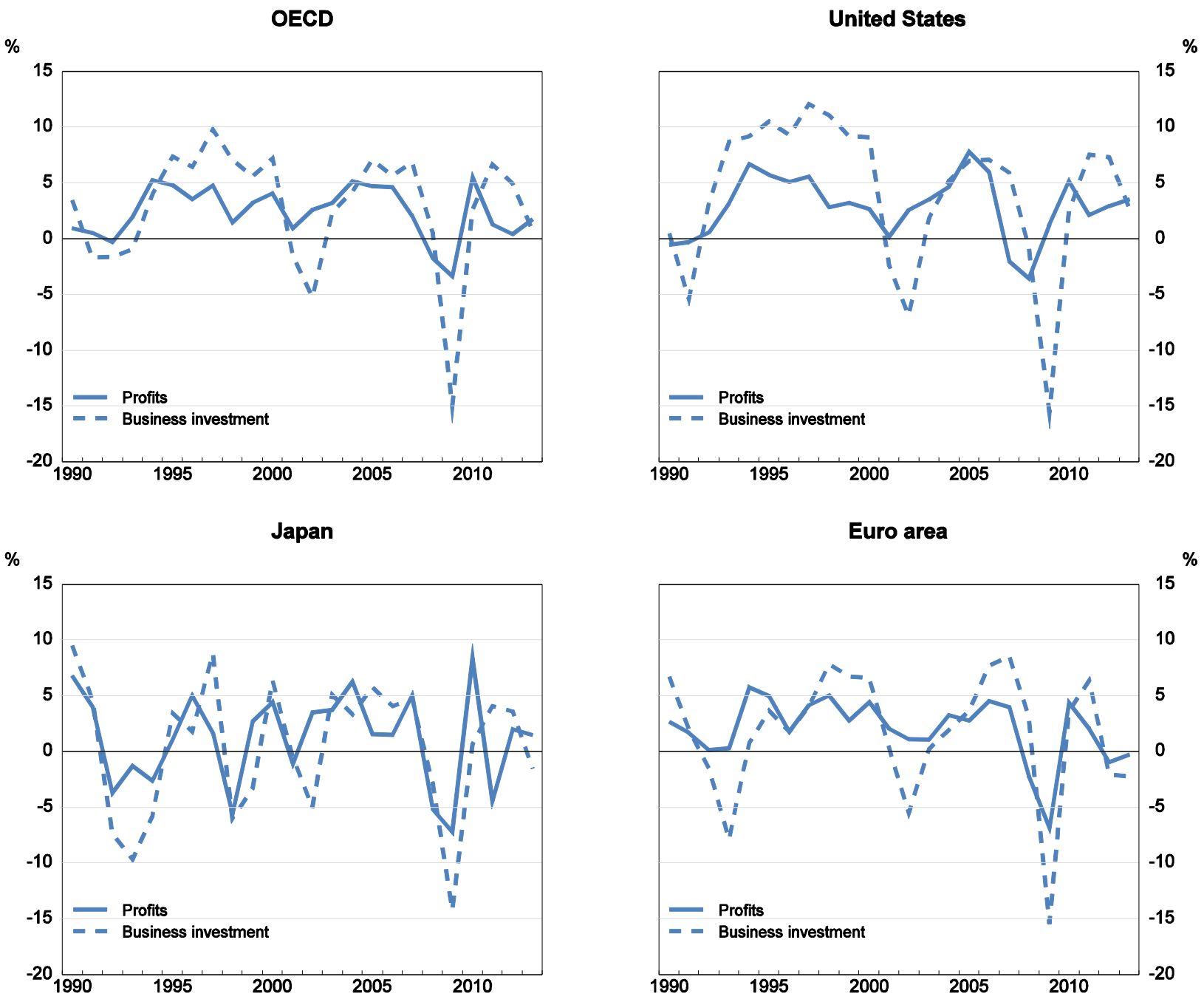

Note: Profits are gross operating surplus less income from self-employment, deflated by the GDP deflator. Countries with less than 19 years of profits data are excluded from the OECD aggregate; there are breaks prior to 1996 in years where additional countries are incorporated.

Source: OECD Economic Outlook database; OECD National Accounts database; and Authors' calculations. 
Figure 13. Financial factors have constrained investment in recent years

Normalised over 1996-2007; in standard deviations

United States

Small firms finding credit is harder to get

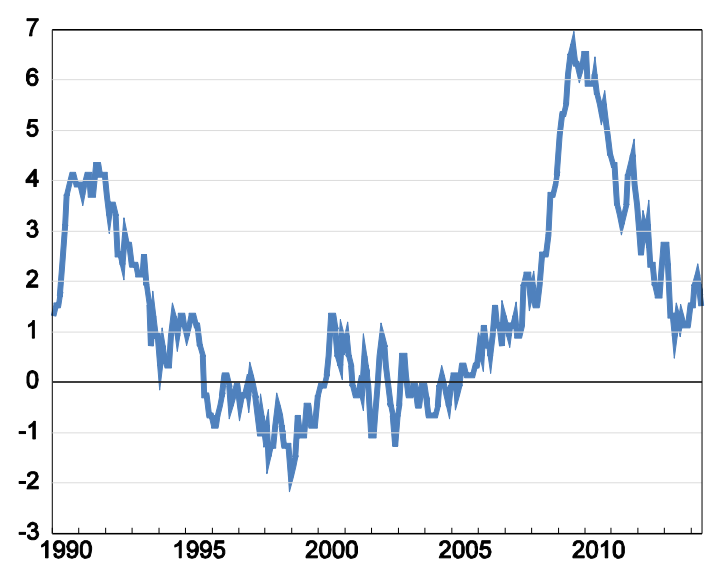

Euro area

Financial factors limiting investment

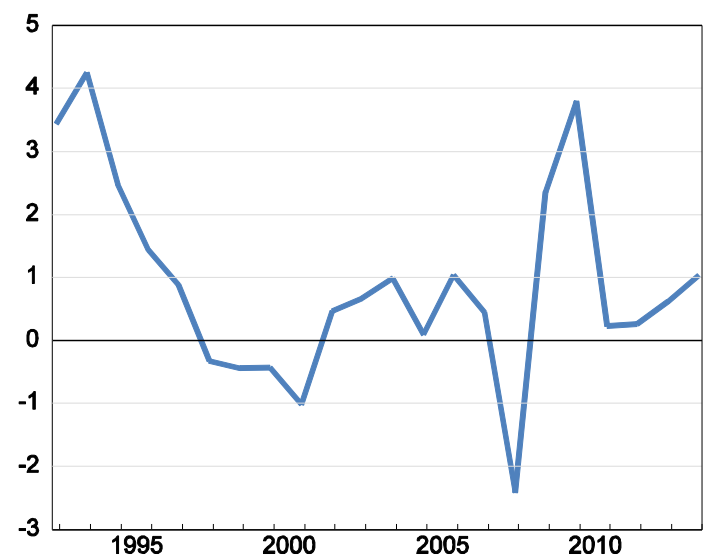

Japan

Firms' financial position

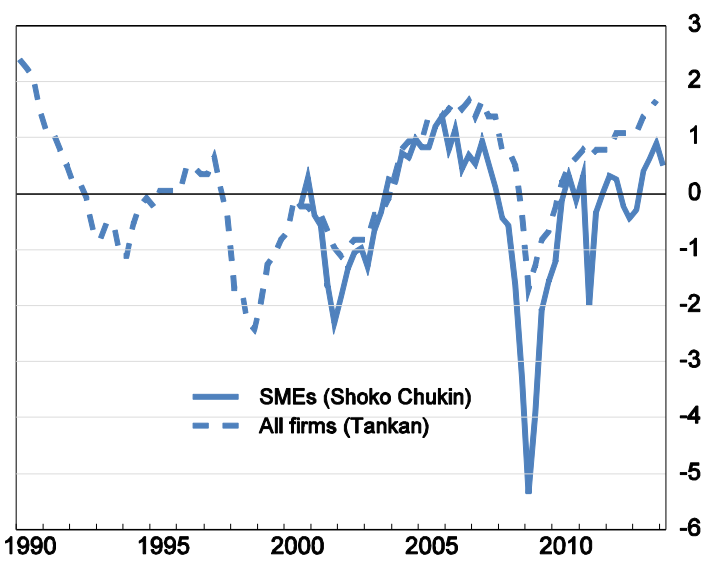

United Kingdom

SMEs with financial constraints on investment

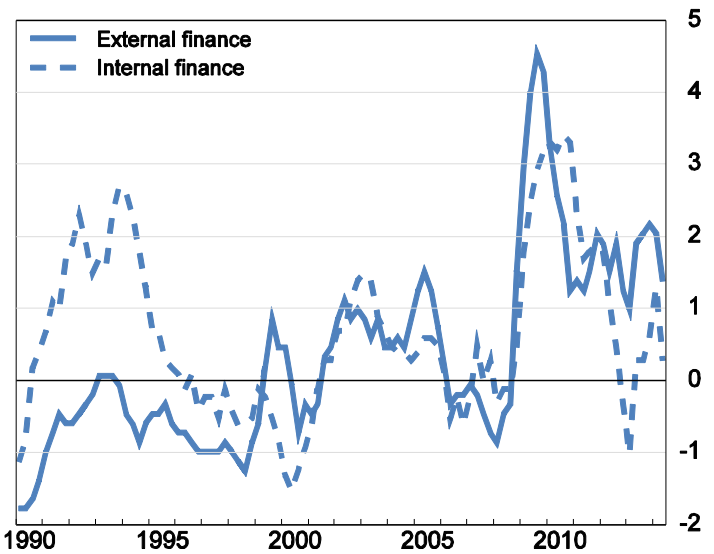

Note: US data are from the NFIB survey and smoothed using a 3-month moving average. UK data are from the CBI survey and smoothed using a 4-quarter moving average. Euro area data are for manufacturing firms.

Source: Datastream; European Commission; and Authors' calculations.

\section{Uncertainty}

23. At times of heightened uncertainty, postponing planned but hard-to-reverse decisions, such as fixed investment, can be a valuable option (Bernanke, 1983; Dixit and Pindyck, 1994), provided the same investment opportunity can be undertaken in the future. Uncertainty can arise from many different sources, although the most important ones are likely to be uncertainty about the state of the economy and about future policy developments. Both forms of uncertainty have risen since the onset of the financial crisis, 
which may have constrained investment, but both have fallen over the past year, likely improving the prospects for a recovery in investment. ${ }^{15}$

24. The appropriate measure of economic uncertainty is far from clear (Davis, 2010), with a range of different indicators having been used in the empirical literature. One widely used measure is stock market volatility, with the empirical evidence generally suggesting that increased volatility, and in particular the peaks in volatility, results in the postponement of investment decisions (Bloom et al., 2007; Bloom, 2009) ${ }^{16}$ Stock market volatility indicators for the United States, euro area and Japan suggest that this measure of uncertainty may also have adversely affected investment since the onset of the crisis (Davis, 2010; OECD, 2011), with volatility rising extremely sharply following the failure of Lehman Brothers in 2008 and also as the euro area crisis intensified significantly in 2010 and again in mid-2011 (Figure 14). These measures returned to low levels after each spike, although in Japan in particular, rises were also seen during the bouts of financial market turbulence of mid-2013 and to a lesser extent in early 2014.

25. The relatively new literature on policy uncertainty and the development of the "Economic Policy Uncertainty Index" (Baker et al., 2013) has highlighted possible linkages between uncertainty, investment growth (European Commission, 2013, 2014) and GDP growth (Haddow et al., 2013). These measures are generally based on news stories related to uncertainty, the economy and policy, together with the dispersion of forecasts of inflation and budget deficits. ${ }^{17}$ They point to elevated levels of uncertainty from 2007 to 2011 (Figure 15), with a sharp rise at the start of the financial crisis and a further increase as the euro area crisis intensified in the latter half of 2011. To this extent, they provide a broadly similar picture to that from stock market volatility, which also rose sharply at these times. However, more recently, the alternative measures of uncertainty have diverged, with stock market volatility declining towards pre-crisis norms, whereas the policy uncertainty indices generally remain elevated relative to the pre-crisis period, even though they have also declined.

26. In the United States, uncertainty was likely related to expiring tax provisions and prospects for new taxes: the "tax code expiration" component of the US policy uncertainty index rose rapidly in each of 2009, 2010 and 2012, reaching unprecedented levels ahead of the prospective fiscal cliff at end-2012 (Figure 16, right-hand panel). Subsequently, the resolution of US budget negotiations and the debt ceiling has removed an important source of uncertainty, which should allow business investment to pick up more strongly, at least for large firms. Small businesses in the United States still highlight uncertainty about regulation as being the greatest constraint on business activity (poor sales, taxes and regulation are currently the largest shares; Figure 16, left-hand panel).

15. The existing literature suggests that the reduction in uncertainty should translate quite quickly into activity measures, although there is a possibility that the relationship between activity and uncertainty may have changed, given that uncertainty has been elevated for such a long period of time (Haddow et al., 2013).

16. Davis (2010) also suggests a role for exchange rate volatility.

17. Measures of policy uncertainty are prone to revision. From April 2014, Economic Policy Uncertainty changed the indices for the European countries and Canada to be based solely on the news-based measure, while the US measure continues to be based on a combination of data on news searches, dispersion of forecasts for key variables and an index of tax code expirations. The full uncertainty index for the United States is used here but it should be noted that the news-based measure has been more volatile and also remained higher than the overall policy measure. 
ECO/WKP(2014)64

Figure 14. Implied volatility of share prices ${ }^{1}$
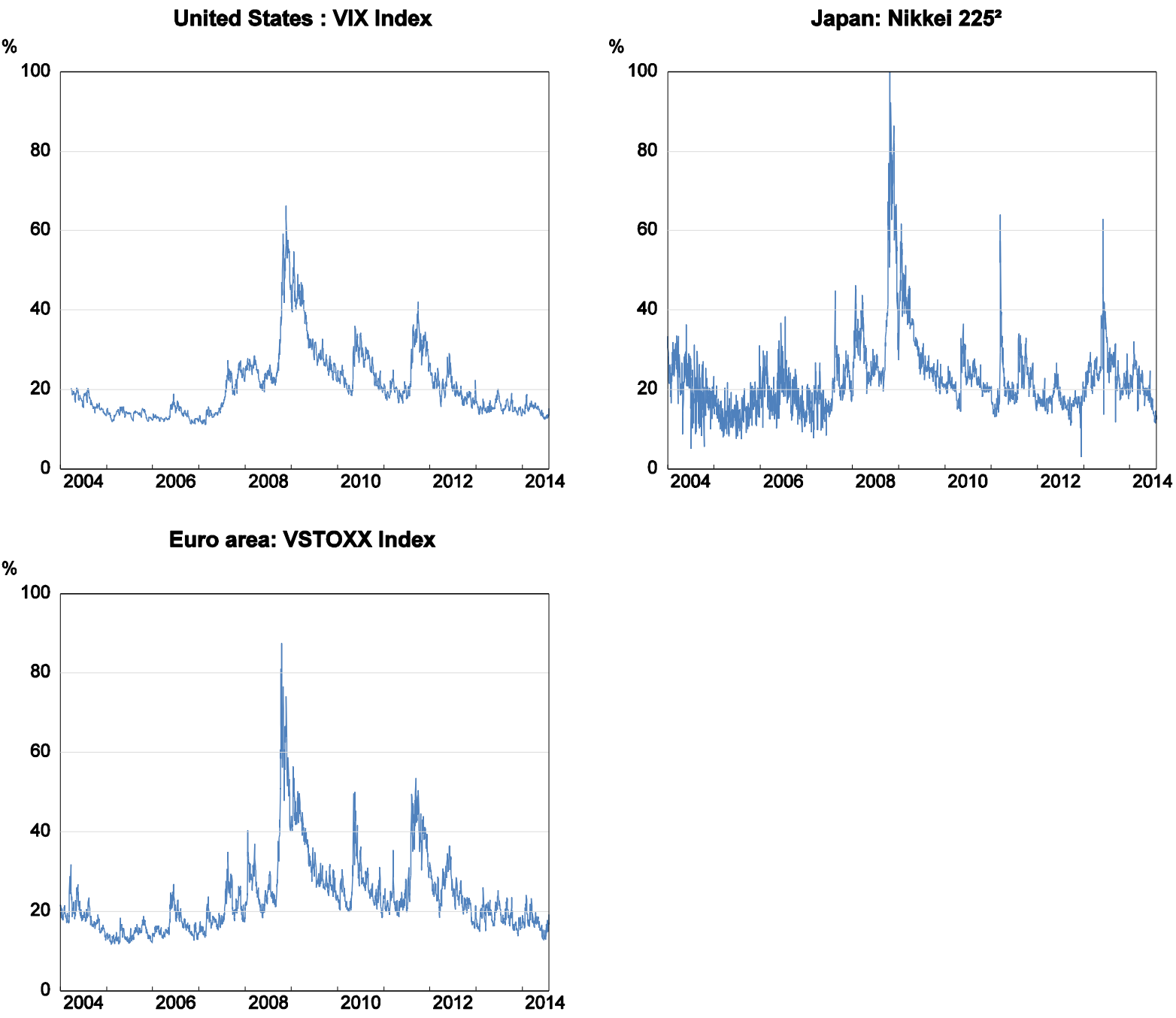

1. Implied volatility can be interpreted as market expectation of risk (future volatility) and is derived from at-the-money call option prices.

2. AMEX prior July 2007.

Source: Datastream. 
Figure 15. Measures of policy uncertainty have fallen but remain elevated

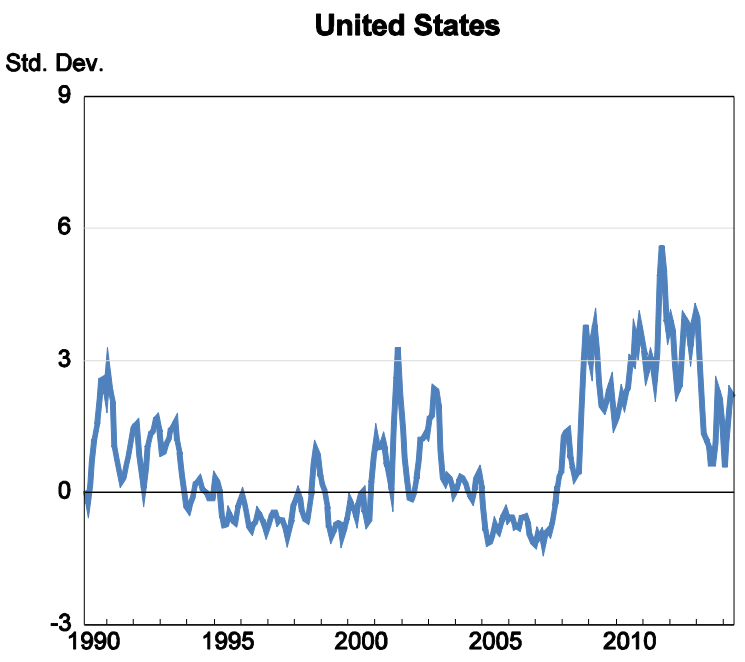

Euro area'

Std. Dev.

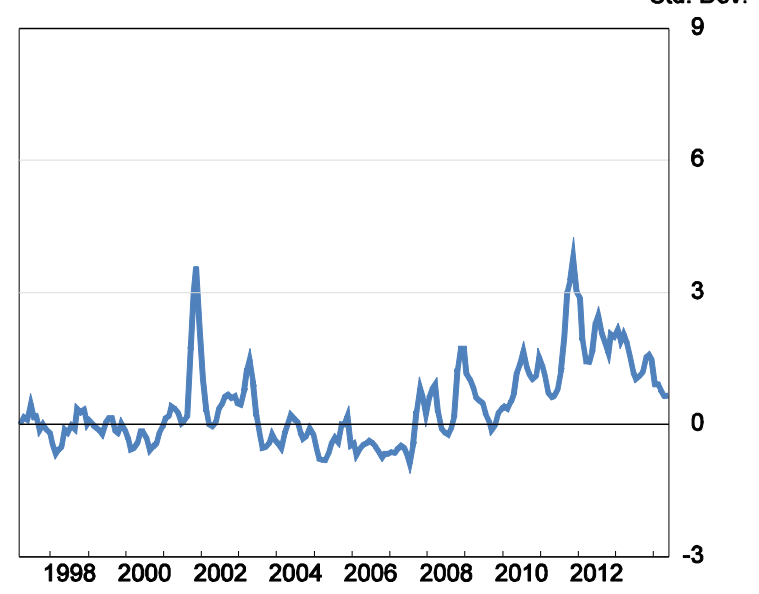

United Kingdom

Major advanced economies ${ }^{2}$
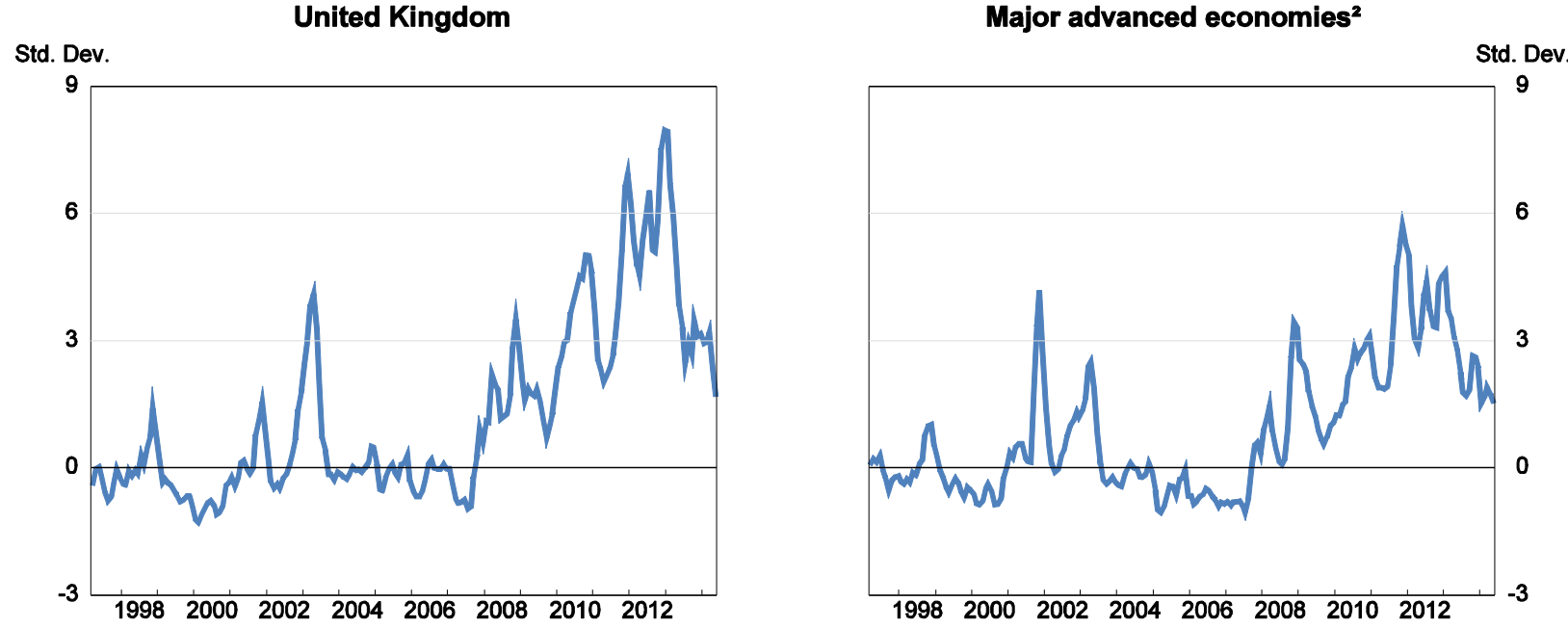

1. Weighted average of the index in the three largest euro area economies.

2. Excluding Japan; first principal component calculated from the Economic Policy Uncertainty Indices for Canada, France, Germany, Italy, the United Kingdom and the United States.

Note: Data shown are a 3-month-moving average of non-seasonally adjusted data which were normalised over the period 1997-2007.

Source: Scott Baker, Nicolas Bloom and Stephen J. Davis at www.PolicyUncertainty.com; and Authors' calculations. 
Figure 16. Regulatory and taxation issues appear to have added to uncertainty in the United States

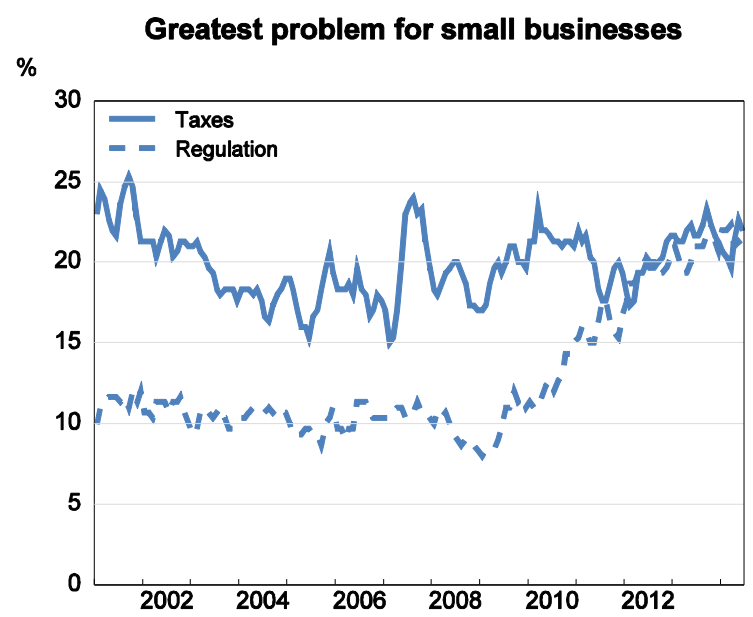

US tax code expirations

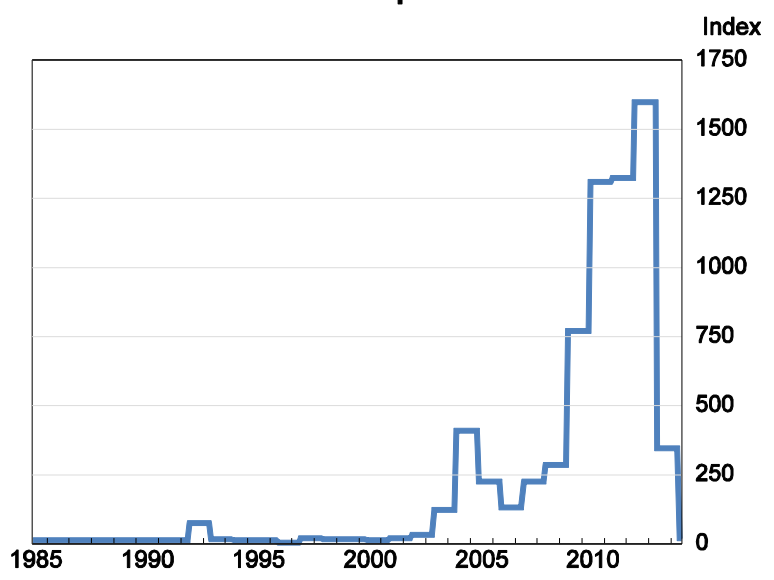

Note: Small business responses are a percentage of total responses from the NFIB survey. Tax code expirations are the weighted sum of the discounted total dollar amount of federal tax code provisions expiring in the following 10 years.

Source: Datastream; Scott Baker, Nicolas Bloom and Stephen J. Davis at www.PolicyUncertainty.com.

27. Concerns about growth prospects and financial vulnerabilities in emerging markets are another potential source of uncertainty. The policy uncertainty indices for China and India point towards heightened levels of uncertainty in recent years, particularly from mid-2011 to mid-2013. While the policy uncertainty index for China has returned toward more normal levels (even though uncertainty about economic prospects may still be high), the index for India remained elevated until more recently. Similarly, measures of equity market volatility in emerging markets suggest uncertainty was elevated during 2011 but is now closer to normal levels, notwithstanding several small bouts of higher volatility.

\section{Regulation and competition}

28. The theoretical impact of greater product market competition on investment is uncertain, since it can either increase the incentives for firms to undertake new investments to stay ahead of competitors or, by hitting the profitability of incumbents, reduce their ability to easily finance new investment. However, empirical evidence suggests that anti-competitive product market regulations, particularly barriers to entry and to trade and competition, are negatively associated with investment and capital accumulation, while reforms can stimulate business investment (Alesina et al., 2005; Nicoletti and Scarpetta, 2005). Since the crisis began, there have been some reductions in product market regulations across the OECD, particularly in the vulnerable euro area countries (Figure 17), improving the prospects for future investment growth. 
Figure 17. Product market regulation has fallen in some, but not all countries

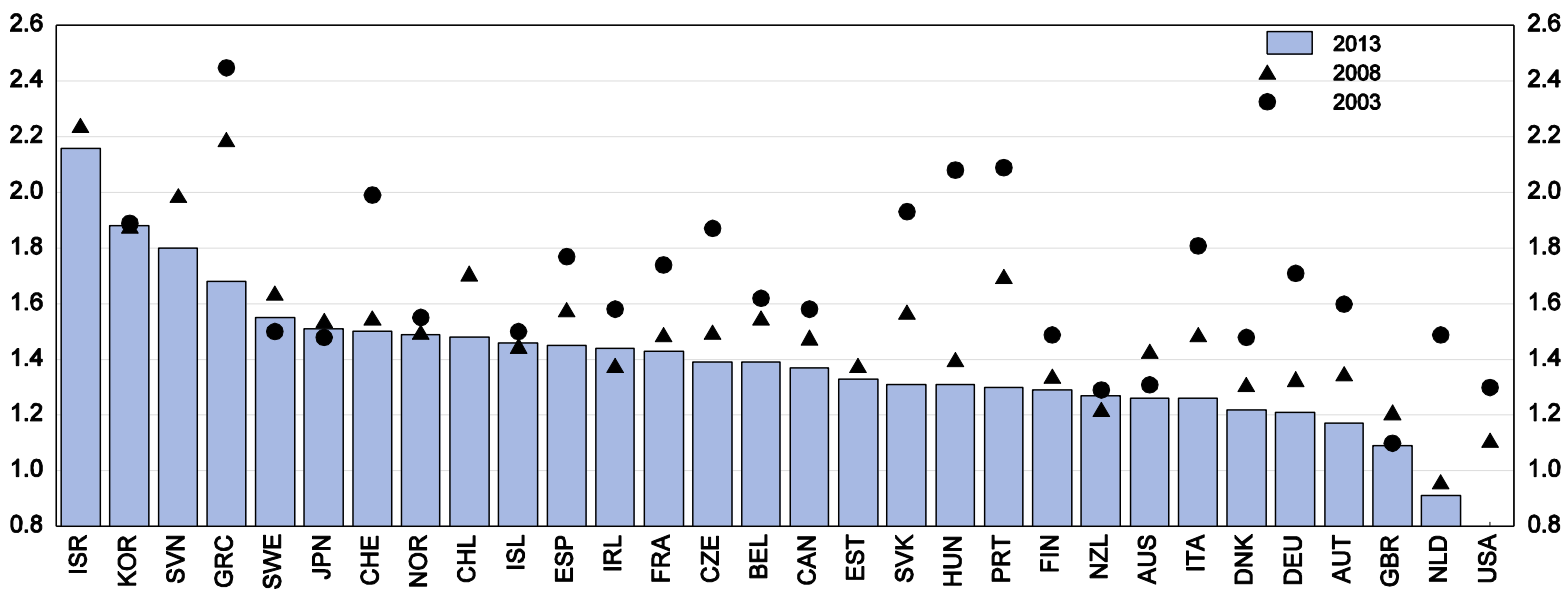

Source: OECD Product Market Regulation database.

\section{Other factors}

29. One possibility for why measured fixed investment has apparently been lower than expected is that there has been a shift from conventionally-measured fixed capital investment to investment in intangible assets, which is largely unmeasured. ${ }^{18}$ Over a long horizon, there is little doubt that a shift from physical to knowledge-based capital (KBC) is underway in advanced economies (Andrews and de Serres, 2012, Andrews and Criscuolo, 2013). The cyclical properties of intangible investment are less well established. On one hand, some forms of intangible asset investment, especially workplace re-organisation and on-the-job training, may have a relatively low opportunity cost (in terms of foregone output) during recessions (López-García et al., 2012), creating a countercyclical effect. But on the other hand, greater credit market frictions, such as the tightening in credit availability during the recent crisis, may disproportionately affect intangible investments that have an uncertain long-term payback (Aghion et al., 2009).

30. The available evidence suggests, however, that in aggregate the shift towards greater investment in intangible assets is only a gradual process and thus unlikely to be major explanatory factor for the weakness of (measured) fixed investment since the crisis. Indeed, there appears to be little evidence of a negative relationship between the changes in investment in intangible assets and tangible assets at an aggregate level during the crisis (using the broad definition of Corrado et al. (2012)). Moreover, R\&D undertaken in the business sector - a component of KBC - appears to have been pro-cyclical, with sizeable falls during the crisis in the G7 countries. However, the falls do appear to have been proportionately smaller than those in total business fixed capital investment (Figure 18). ${ }^{19}$ In part this may be because government-financed business R\&D cushioned the initial fall in $R \& D$ expenditure, although government R\&D budgets have subsequently declined.

18. Data from Corrado et al. (2012) reveal that for many OECD countries, less than one-quarter of intangible investment was included in the national accounts in 2010. The adoption of the 2008 System of National Accounts (SNA) will increase the proportion that is measured, although data from countries with the new SNA show that its importance varies: intellectual property products accounted for around 30 per cent of US business fixed investment in 2013, but around 10\% in Canada and 15\% in Australia.

19. R\&D expenditure is not currently measured as investment in most OECD countries' national accounts. 
Figure 18. Growth in G7 business R\&D and investment

G7 countries weighted average, annual percentage change

$\%$

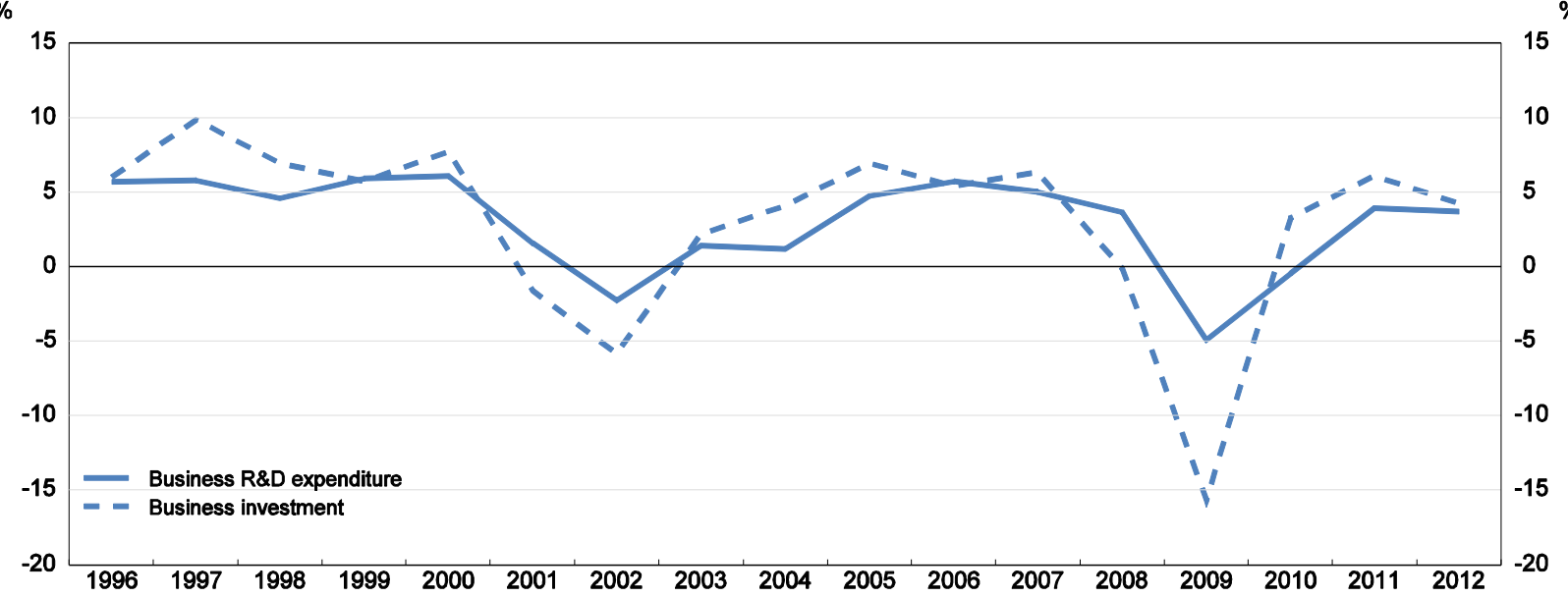

Note: Weighted average of G7 countries; business investment data exclude Italy.

Source: OECD, Main Science and Technology Indicators database; OECD Economic Outlook database; and Authors' calculations.

31. Another possibility is that companies in the major OECD economies have chosen to expand by investing outside their home country, with weak domestic market growth also acting as a deterrent to inward investment in these economies. Timely measures are hard to obtain, apart from information on foreign direct investment, which can be used for many purposes other than fixed investment. The empirical evidence on the relationship between aggregate outward investment and domestic investment is mixed (Globerman, 2012), though firm-level evidence suggests that multinational firms typically expand both investment at home and abroad (Desai et al., 2009). The gap between outward and inward FDI has however opened up since the crisis began (Figure 19), with outward investment picking up to pre-crisis norms, but inward investment being weaker. This raises the possibility that restrictions on inward direct investment in some countries could be limiting new inward investment that might otherwise help to strengthen total domestic fixed investment growth. 
Figure 19. G7 FDI net outflows have risen relative to domestic investment since the crisis began

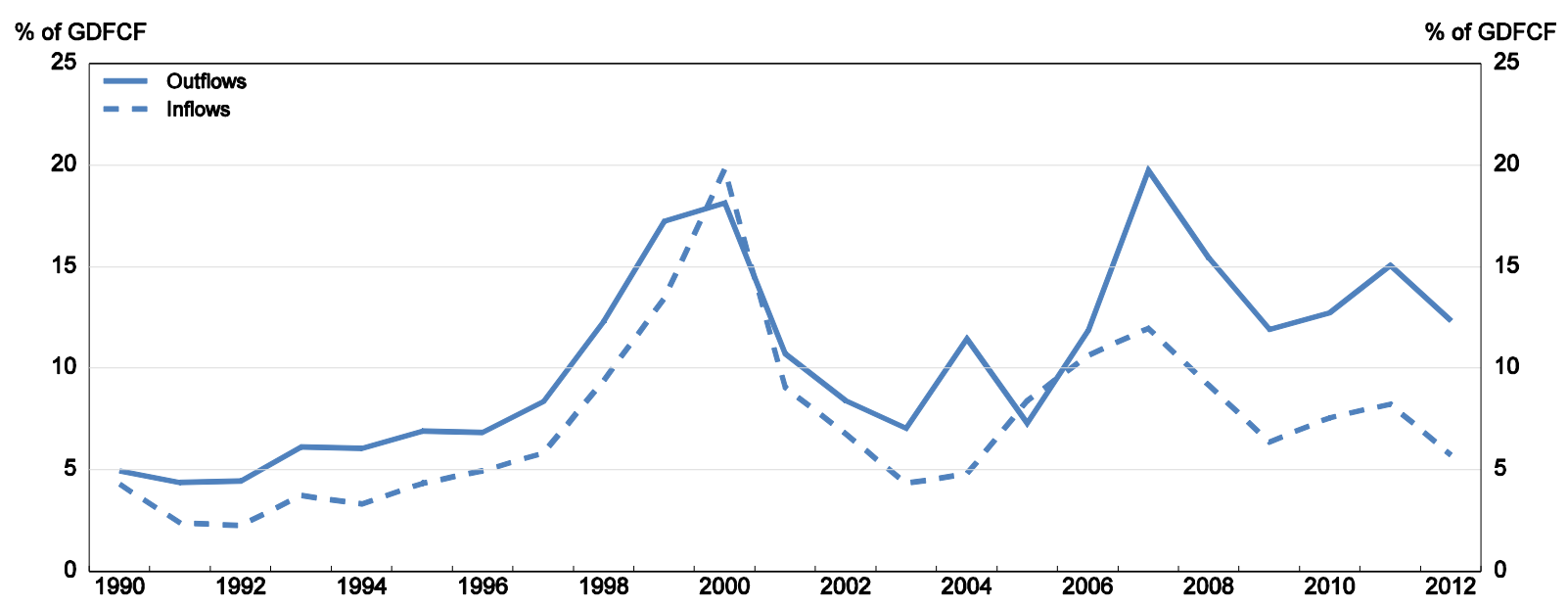

Note: GDFCF is gross domestic fixed capital formation. G7 countries are weighted using nominal fixed investment at PPP rates.

Source: UNCTAD; and Authors' calculations.

\section{Implications for policy}

\section{Business investment}

32. In addition to the support to demand provided by macroeconomic policies, which will likely stimulate investment through the accelerator effect, there are a number of specific investment-focussed policies that could help to boost investment and thereby strengthen the momentum of the recovery. Policy changes are also needed to help tackle longer-term issues that bear on investment decisions indirectly and to reduce financial fragmentation in the euro area.

33. A decline in the user cost of capital would help to stimulate business investment, all else being equal. Reductions in corporate bond yields as a result of very accommodative monetary policy have probably already lowered the user cost of capital for large companies, but the widening of bank lending spreads in countries inside and outside the euro area has partially or fully offset such effects for smaller companies that cannot raise funds in the bond market. Much of the widening gap between bank lending rates and government bond yields is likely due to increased credit risk, which should diminish as the recovery firms and banks' balance sheets strengthen, and to higher perceived counterparty risk in funding markets, especially in the euro area. The latter will likely be reduced if the upcoming comprehensive assessment of euro area banks is seen to be fully credible and any associated bank recapitalisation is undertaken swiftly. Even so, bank lending spreads in all economies may have increased permanently as a result of higher capital requirements for banks following the crisis. ${ }^{20}$

34. Since the onset of the crisis, many governments have also lowered the user cost of capital, at least temporarily, by introducing temporary tax credits or accelerated depreciation of capital equipment for tax purposes. Temporary tax breaks can, in principle, have powerful effects by advancing capital spending, but may also be associated with dead-weight costs. In countries where the recovery in capital spending is now progressing, there is less need to give such tax support to investment. There the focus should shift to

20. Slovik and Cournède (2011) estimate that the capital requirements in Basel III, effective as of 2019, could increase bank lending spreads by about 50 basis points. 
reforms of the corporate tax system to avoid a repeat of the excessive tax-induced pre-crisis build-up of debt relative to equity, which can result in sharp investment compression if negative shocks occur.

35. To the extent that the availability of internal finance acts as a constraint on investment, average corporate tax rates also matter as well as marginal ones. Reductions in marginal rates financed by a broadening of the tax base will not necessarily improve cash flow, and the impact of policy changes will be dependent upon the wider state of firms' balance sheets. This does not mean that the tax system should always be biased in favour of internal finance, since a higher proportion of internal finance may offer managers greater discretion to pursue policies at odds with the wishes of external investors. Much then depends on the efficacy of corporate governance.

36. A relaxation of product market regulations should also help to raise investment. This is notably the case for the lowering of entry barriers, including those facing foreign investors, but reducing red tape and other forms of regulatory burdens can also lower firms' costs of adjusting their capital stock (Alesina et al., 2005). According to a recent update of the OECD product market regulation indicators (OECD, 2014b), only modest moves have been taken to reduce competition-restraining regulations over the past five years in most OECD countries, and an intensification of such reform efforts would be rewarded by higher business investment. Further steps at the EU level to strengthen and deepen the Single Market would also help to boost investment prospects.

37. Although measures of uncertainty related to government policy and the economic outlook have fallen significantly and is now unlikely to be restraining capital spending significantly, outside of the euro area, there is a risk that it could resurface if consensus is lacking on how to address future problems. Significant long-term fiscal challenges related to retirement income and health care remain to be tackled, and businesses may become reluctant to invest if there is uncertainty about the way such spending pressures will be financed. Forging a timely agreement on how to solve such long-term challenges would give businesses better visibility about the profitability of potential investment projects and spur capital spending. Incentives to undertake additional investments might also be boosted by a successful conclusion to the current negotiations on the transatlantic and transpacific trade agreements. Policy uncertainty in emerging markets could also be reduced by reforms in these economies to strengthen growth prospects and guard against financial vulnerabilities.

\section{Public investment}

38. While public investment has held up relatively well in the downturn and the recovery, it could be argued that government investment should have been stronger over this period. This is because of high multiplier effects and the long-term economy-wide benefits associated with such capital spending. Moreover, advanced economies are widely estimated to have large investment requirements to upgrade or replace ageing infrastructure, ${ }^{21}$ and starting to make up for the shortfall when private investment was weak, and government borrowing rates low, would have been ideal. Looking forward, despite major fiscal challenges in advanced economies, governments should be able to reduce debt towards more prudent levels without needing to cut back investment provided that less growth-friendly public spending is scaled back and margins to reform the tax system are used (Cournède et al., 2013).

21. The total requirement for global infrastructure investment by 2030 for transport, electricity generation, transmission and distribution, water and telecommunications is estimated by the OECD to be around USD70 trillion, which amounts to about $3.5 \%$ of global GDP over the same period. 


\section{ECO/WKP(2014)64}

\section{Housing investment}

39. Since the downturn, strong monetary stimulus and associated very low mortgage rates have supported housing investment, and as households have made progress in repairing their balance sheets, they have become more willing to take advantage of low borrowing costs. In some countries, additional support has been provided, the Help to Buy and Funding for Lending Scheme in the United Kingdom being notable examples. However, as residential property markets recover, the priority should be to change policies that are at the root of repeated boom-and-bust housing cycles in many countries, notably tax advantages for owner-occupation and cumbersome land use and planning restrictions that limit the price responsiveness of housing supply (Andrews et al., 2011). 


\section{BIBLIOGRAPHY}

Aghion, P., D. Hemous, and E. Kharroubi (2009), "Credit Constraints, Cyclical Fiscal Policy and Industry Growth”, NBER Working Paper, No. 15119.

Alesina, A., S. Ardagna, G. Nicoletti and F. Schiantarelli (2005), "Regulation and Investment", Journal of the European Economic Association, Vol.3, No.4 (June), pp.791-825

Andrews, D., A. Caldera Sánchez and Å. Johansson (2011), "Housing Markets and Structural policies in OECD Countries", OECD Economics Department Working Papers, No. 836, OECD Publishing.

Andrews, D. and A. de Serres (2012), "Intangible Assets, Resource Allocation and Growth: A Framework for Analysis", OECD Economics Department Working Papers, No.989, OECD Publishing.

Andrews, D. and C. Criscuolo (2013), "Knowledge Based Capital, Innovation and Resource Allocation", OECD Economics Department Working Papers, No. 1046, OECD Publishing.

Baker, S., N. Bloom and S. Davis (2013), "Measuring Economic Policy Uncertainty", Chicago Booth Research Paper, No 13-02.

Bernanke, B. (1983), "Irreversibility, Uncertainty and Cyclical Investment", Quarterly Journal of Economics, Vol. 98.

Bates, T.W., K.M. Kahle, and R.M. Stulz (2009), "Why Do U.S. Firms Hold so Much More Cash than They Used To?", Journal of Finance, Vol. 64.

Bean, C. (1981), “An Econometric Model of Manufacturing Investment in the UK”, Economic Journal, 91, pp. 106-121.

Benito, A. and G. Young (2007), "Financial pressure and balance sheet adjustment by firms", Oxford Bulletin of Economics and Statistics, Vol. 69.

Bloom, N. (2009), “The Impact of Uncertainty Shocks”, Econometrica, Vol. 77.

Bloom, N., S. Bond and J. van Reenen (2007), "Uncertainty and Investment Dynamics", Review of Economic Studies, Vol. 74, No. 3, pp. 391-415.

Blundell, R. and S. Bond (1998), "Initial Conditions and Moment Restrictions in Dynamic Panel Data Models", Journal of Econometrics, Vol. 87, No. 1, pp. 115-143.

Blundell-Wignall, A. and C. Roulet (2014), "Macro-prudential policy, bank systemic risk and capital controls", OECD Journal: Financial Market Trends, Vol. 2013/2.

Bond. S., J.A. Elston, J. Mairesse and B. Mulkay (2003), "Financial Factors and Investment in Belgium, France, Germany and the United Kingdom: A Comparison Using Company Panel Data", Review of Economics and Statistics, Vol. 85. 
Corrado, C., J. Haskel, C. Jona-Lasinio and M. Iommi (2012), "Intangible Capital and Growth in Advanced Economies: Measurement Methods and Comparative Results", Working Paper, available at http://www.intan-invest.net.

Chirinko, R. (1993), "Business Fixed Investment Spending: Modelling Strategies, Empirical Results, and Policy Implications”, Journal of Economic Literature, Vol. XXXI, pp. 1875-1911.

Cournède, B. (2010), "Gauging the Impact of Higher Capital and Oil Costs on Potential Output", OECD Economics Department Working Papers, No. 789.

Cournède, B., A. Goujard, A. Pina and A. de Serres (2013), "Choosing Fiscal Consolidation Instruments Compatible with Growth and Equity", OECD Economic Policy Papers, No. 7, OECD Publishing.

Davis, E. P. (2010), "Asset Prices and Real Economic Activity", OECD Economics Department Working Papers, No. 764, OECD Publishing.

Desai, M., C.F. Foley, and J.R. Hines (2009), "Domestic Effects of the Foreign Activities of U.S. Multinationals." American Economic Journal: Economic Policy 1, no. 1 (2009): 181-203.

Dixit, A. and R.S. Pindyck, (1994), Investment Under Uncertainty. Princeton University Press.

ECB (2013): "The Perceived External Financing Gap Indicator for Small and Medium-sized Enterprises in the Euro Area", Box 2, ECB Monthly Bulletin, August, pp. 19-24.

European Commission (2013), "Box 1.2: The Impact of Uncertainty on Productive Investment", Quarterly report on the euro area, No 12/2.

European Commission (2014), "Box 1.1: The Economic Effects of Policy Uncertainty", European Economic Forecast - Winter 2014.

Globerman, S. (2012), Canadian Outward FDI and Its Implications for the Canadian Economy, report for The Conference Board of Canada, May 2012.

Haddow, A., C. Hare, J. Hooley and T. Shakir (2013), "Macroeconomic Uncertainty: What Is It, How Can We Measure It and Why Does It Matter?", Bank of England Quarterly Bulletin, Q2.

Hall, R. and D. Jorgenson (1967), "Tax Policy and Investment Behaviour", American Economic Review, June 1967.

López-García, P., J.M. Montero and E. Moral-Benito (2012), "Business Cycles and Investment in Intangibles: Evidence from Spanish Firms", Banco de Espana Working Paper, No. 1219.

Nicoletti, G. and S. Scarpetta (2005), "Regulation and Economic Performance: Product Market Reforms and Productivity in the OECD", OECD Economics Department Working Papers, No. 460, OECD Publishing.

OECD (2008), OECD Economic Outlook May 2008, OECD Publishing.

OECD (2010), Tax Policy Reform and Economic Growth, OECD Publishing.

OECD (2011), "Risk Awareness, Uncertainty and Confidence", Box 1 in OECD Economic Outlook, November 2011, OECD Publishing. 
OECD (2014a), "Growth Prospects and Fiscal Requirements over the Long Term", chapter 4 in OECD Economic Outlook May 2014, OECD Publishing.

OECD (2014b), Economic Policy Reform 2014: Going for Growth Interim Report, OECD Publishing.

Pelgrin, F., S. Schich and A. de Serres (2002), "Increases in Business Investment Rates in OECD Countries in the 1990s: how much can be explained by fundamentals?", OECD Economics Department Working Papers, No. 327.

Pinto, E. and S. Tevlin (2014), "Perspectives on the Recent Weakness in Investment", FEDS Notes, 21 May 2014, Federal Reserve.

Ruscher, E. and G.B. Wolff (2012), "Corporate Balance Sheet Adjustment: Stylised Facts, Causes and Consequences”, European Economy Economic Papers, No. 449.

Sánchez, J.M. and E. Yurdagul (2013), "Why are Corporations Holding So Much Cash?”, The Regional Economist, January 2013, Federal Reserve Bank of St. Louis.

Slovik, P. and B. Cournède (2011), "Macroeconomic Impact of Basel III", OECD Economics Department Working Papers, No. 844, OECD Publishing. 


\section{APPENDIX 1: A SIMPLE BASELINE MODEL OF BUSINESS INVESTMENT}

1. This appendix reports estimates of a simple baseline model of business investment and uses this model to obtain a decomposition of the forces acting on investment since the onset of the crisis.

2. In a standard neo-classical model of investment, the long-run demand for capital can be derived from a production function using the first order condition that the marginal product of capital should equal its real price. This can be rearranged to show that the long-run desired capital stock depends on output and the real user cost of capital. Assuming further that net investment is a distributed lag process of changes in the desired capital stock (partial adjustment) or, alternatively, that changes in the existing capital stock are associated with adjustment costs, an empirically-tractable equation without the existing capital stock can be obtained (Bean, 1981; Pelgrin et al., 2002; Davis, 2010). This approach enables the statistical issues associated with the measurement and comparability of cross-country capital stocks to be avoided. Allowing for the adjustment costs of investment also implies a role for lagged investment and output growth (the accelerator effect).

3. A model is estimated using an unbalanced panel dataset covering 13 OECD economies, with quarterly data from 1993Q1 to 2013Q3 based on data available as of April 2014. The baseline model contains the basic determinants implied by neo-classical-type models and also allows for changes in the depreciation rate of capital, real equity prices (which may capture some corporate balance sheet effects and Tobin's Q), and capacity utilisation, proxied by the output gap (with a prior that a more negative output gap reduces the need to undertake new investment). A role for other potentially relevant variables is also considered, namely the availability of internal funds (real corporate profits), policy uncertainty indices (at a country level and also using the first principal component) and realised share price volatility (a second proxy for uncertainty). To increase the sample size, a simplified user cost of capital is used (abstracting from the tax effects in equation 1), with the user cost a function of the relative price of investment goods, real interest rate and depreciation rate.

4. All variables are in logs, apart from the output gap, uncertainty and stock market volatility. Following Pelgrin et al. (2002), the user cost of capital enters as $\log (1+\mathrm{UCC})$. Data sources are summarised in Table A.1. A least squares dummy variable approach is used to capture individual country effects.

5. Representative empirical results are set out in Table A.2. Column 1 shows the freely estimated long-run coefficients on investment, output and the cost of capital, with the retained covariates. The longrun coefficient on the cost of capital is found to be negative (as expected) but insignificant, as is commonly the case in empirical investment models. There is a statistically significant long-run stock price effect and effect from the output gap, as well as effects of changes in the user cost (largely driven by interest rate changes) and output growth. The latter has a coefficient well above unity, pointing to the importance of the accelerator effect.

6. A restricted version of the same model is also shown (column 2) with the (statistically-acceptable) imposition of a long-run coefficient of unity on output and minus 1 on the real user cost of capital, implying constant returns to scale and a unit elasticity of substitution. The estimated equilibrium-correction coefficient is statistically significant and, at around -0.2, suggests investment adjusts fairly rapidly towards its long-run level.

7. Several robustness checks are considered in Table A.3. A system generalised method of moments (GMM) estimator (Blundell and Bond, 1998) is shown, given the possibility of bias due to correlations between the lagged dependent variable and any endogenous variables (such as output growth) and the 
country fixed effects (Columns 1 and 2). (Although with the reasonably long time period, bias due to the fixed effects should be limited.) Estimates from the pre-crisis period are also similar (Column 3). Other variables, such as uncertainty, do not improve the model (Columns 4 to 7).

8. The estimated equations can be used to obtain an accounting decomposition of the influences of different factors on investment growth in each country included in the panel. This is illustrated in Figure A.1, which uses the final equation in Table A.2 to decompose the year-on-year growth of investment into contributions from output, the output gap and the real user cost, growth in real equity prices and changes in the depreciation rate. The difference between the sum of these contributions and the actual growth of investment is shown in the category "Residual" in the figure. Key points include:

- In most countries, the downturn in 2008-09 is reasonably well-captured by this simple baseline model, with output growth and subsequently the large negative output gap accounting for a sizeable proportion of observed investment dynamics, including in the United States and Japan. The output gap can also account for a considerable proportion of the muted recovery in investment in recent years, especially in France and the Netherlands.

- The user cost of capital and the real stock price can account for only a small proportion of the swings in investment. Both helped to push down investment growth in 2009. More recently, in 2013, the strength of the stock market has been a supportive influence in 2013, whereas the user cost has been a modest drag on investment.

- Investment was weaker than the baseline model would predict in 2011 and 2012, particularly in some euro area countries and the United Kingdom, which is consistent with the view that uncertainty weighed on investment growth in these years. (Although Table A.3 shows that no systematic role could be found for the available uncertainty measures.)

- The large cross-country variation in the pattern of the "residual" factors suggests that there might be considerable underlying heterogeneity in investment behaviour across countries. For instance, it is notable that investment growth in the United States and Canada over 2010-12 was consistently stronger than be accounted for by the baseline model.

Table A.1. Data description

\begin{tabular}{ll} 
Variable & Description \\
\hline Investment & Real business fixed investment (log) \\
Output & Real GDP (log) \\
Gap & Output gap (in per cent) \\
UCC & User cost of capital (as described in text; log $(1+\mathrm{UCC})$ ) \\
Depreciation & Scrapping rate (log) \\
Share price & Share price index deflated by GDP deflator (log) \\
Corporate profits & Corporate profits (gross operating surplus + gross mixed income) deflated by \\
& GDP deflator (log) \\
Policy uncertainty & Policy Uncertainty Indices as published on PolicyUncertainty.com \\
Financial uncertainty & Share price volality: squared standard deviation of MSCl daily share price index \\
& in local currency \\
\hline
\end{tabular}


Table A.2. Panel regression results

Dependent variable is quarterly real business investment growth

\begin{tabular}{|c|c|c|}
\hline & $\begin{array}{c}(1) \\
\text { Unrestricted }\end{array}$ & $\begin{array}{c}(2) \\
\text { Restricted }\end{array}$ \\
\hline$\Delta$ Output & $\begin{array}{c}1.7428^{* \star *} \\
(0.167)\end{array}$ & $\begin{array}{c}1.7144^{* * *} \\
(0.157)\end{array}$ \\
\hline$\triangle \mathrm{UCC}$ & $\begin{array}{c}-0.6150^{* *} \\
(0.229)\end{array}$ & $\begin{array}{c}-0.6786^{\star \star *} \\
(0.179)\end{array}$ \\
\hline Gap (t-1) & $\begin{array}{c}0.0035^{\star \star \star} \\
(0.001)\end{array}$ & $\begin{array}{c}0.0036^{* * *} \\
(0.001)\end{array}$ \\
\hline$\Delta$ Depreciation & $\begin{array}{c}0.3095^{\star * *} \\
(0.070)\end{array}$ & $\begin{array}{c}0.3031^{* * *} \\
(0.072)\end{array}$ \\
\hline Share price $(t-1)$ & $\begin{array}{c}0.0278^{* *} \\
(0.009)\end{array}$ & $\begin{array}{c}0.0287^{\star * *} \\
(0.006)\end{array}$ \\
\hline Investment (t-1) & $\begin{array}{c}-0.2187^{* \star *} \\
(0.029)\end{array}$ & \\
\hline Output (t-1) & $\begin{array}{c}0.2468^{\star \star \star} \\
(0.044)\end{array}$ & \\
\hline UCC $(t-1)$ & $\begin{array}{l}-0.0856 \\
(0.173)\end{array}$ & \\
\hline Equilibrium correction term (t-1) & & $\begin{array}{c}-0.2119^{* * *} \\
(0.028)\end{array}$ \\
\hline Constant & $\begin{array}{c}-1.4385^{*} \\
(0.780) \\
\end{array}$ & $\begin{array}{c}-0.5700^{* * *} \\
(0.066) \\
\end{array}$ \\
\hline Observations & 1,069 & 1,069 \\
\hline Number of countries & 13 & 13 \\
\hline R-squared & 0.332 & 0.329 \\
\hline F-tests of long-run coefficients & & \\
\hline Investment $=-$ Output & 1.342 & \\
\hline$p$-value & 0.269 & \\
\hline Investment $=-$ Output $=$ UCC & 0.673 & \\
\hline p-value & 0.528 & \\
\hline
\end{tabular}

Note: See Table A.1 for a description of the variables. The equilibrium correction term is calculated as the difference between investment and its long-run equilibrium level given by output and the user cost of capital in period t-1. Coefficients on country dummy variables are not shown; United States is the base country. Robust standard errors clustered by country shown in parentheses. ${ }^{\star \star \star}$ $p<0.01,{ }^{* *} p<0.05,{ }^{*} p<0.1$

Source: Authors' calculations. 
ECO/WKP(2014)64

Table A.3. Robustness checks

Dependent variable is quarterly real business investment growth

\begin{tabular}{|c|c|c|c|c|c|c|c|}
\hline & $\begin{array}{c}\text { (1) } \\
\text { System } \\
\text { GMM }\end{array}$ & $\begin{array}{c}(2) \\
\text { System } \\
\text { GMM }\end{array}$ & $\begin{array}{c}\text { (3) } \\
\text { Pre-crisis } \\
\text { sample }\end{array}$ & $\begin{array}{c}(4) \\
\text { With all } \\
\text { financial } \\
\text { variables }\end{array}$ & $\begin{array}{c}\text { (5) } \\
\text { With financial } \\
\text { uncertainty }\end{array}$ & $\begin{array}{c}(6) \\
\text { With country- } \\
\text { specific policy } \\
\text { uncertainty }\end{array}$ & $\begin{array}{c}(7) \\
\text { With common } \\
\text { policy } \\
\text { uncertainty }\end{array}$ \\
\hline & Unrestricted & Restricted & Unrestricted & Unrestricted & Unrestricted & Unrestricted & Unrestricted \\
\hline$\Delta$ Output & $\begin{array}{c}1.6638^{\star \star \star} \\
(0.224)\end{array}$ & $\begin{array}{c}1.6246^{\star \star \star} \\
(0.188)\end{array}$ & $\begin{array}{c}2.2939^{\star \star \star} \\
(0.229)\end{array}$ & $\begin{array}{c}1.6177^{\star \star \star} \\
(0.223)\end{array}$ & $\begin{array}{c}1.9506^{\star \star *} \\
(0.167)\end{array}$ & $\begin{array}{c}1.9566^{\star \star \star} \\
(0.179)\end{array}$ & $\begin{array}{c}1.9675^{\star \star \star} \\
(0.197)\end{array}$ \\
\hline$\triangle \mathrm{UCC}$ & $\begin{array}{c}-0.6942^{\star \star \star} \\
(0.250)\end{array}$ & $\begin{array}{c}-0.8539^{\star \star *} \\
(0.196)\end{array}$ & $\begin{array}{r}-0.3919 \\
(0.286)\end{array}$ & $\begin{array}{l}-0.4593 \\
(0.286)\end{array}$ & $\begin{array}{l}-0.5307^{*} \\
(0.262)\end{array}$ & $\begin{array}{l}-0.5205^{\star} \\
(0.264)\end{array}$ & $\begin{array}{l}-0.5271^{*} \\
(0.269)\end{array}$ \\
\hline Gap (t-1) & $\begin{array}{l}0.0038^{\star \star \star} \\
(0.001)\end{array}$ & $\begin{array}{c}0.0038^{\star \star \star} \\
(0.001)\end{array}$ & $\begin{array}{c}0.0067^{\star \star \star} \\
(0.002)\end{array}$ & $\begin{array}{c}0.0036^{\star \star \star} \\
(0.001)\end{array}$ & $\begin{array}{c}0.0053^{\star \star \star} \\
(0.001)\end{array}$ & $\begin{array}{c}0.0053^{\star \star *} \\
(0.001)\end{array}$ & $\begin{array}{c}0.0055^{\star \star \star} \\
(0.001)\end{array}$ \\
\hline$\Delta$ Depreciation & $\begin{array}{c}0.3702^{\star \star \star} \\
(0.094)\end{array}$ & $\begin{array}{c}0.3558^{\star \star \star} \\
(0.108)\end{array}$ & & & & & \\
\hline Share price $(\mathrm{t}-1)$ & $\begin{array}{c}0.0378^{\star \star} \\
(0.015)\end{array}$ & $\begin{array}{c}0.0397^{\star \star \star} \\
(0.011)\end{array}$ & & $\begin{array}{c}0.0268^{\star \star} \\
(0.011)\end{array}$ & & & \\
\hline Investment (t-1) & $\begin{array}{c}-0.2808^{\star \star \star} \\
(0.045)\end{array}$ & & $\begin{array}{c}-0.1939^{* * *} \\
(0.029)\end{array}$ & $\begin{array}{l}-0.2308^{\star \star \star} \\
(0.035)\end{array}$ & $\begin{array}{c}-0.1910^{\star \star \star} \\
(0.030)\end{array}$ & $\begin{array}{l}-0.1919^{\star \star \star} \\
(0.029)\end{array}$ & $\begin{array}{l}-0.1916^{\star \star \star} \\
(0.029)\end{array}$ \\
\hline Output (t-1) & $\begin{array}{l}0.3370^{\star \star *} \\
(0.070)\end{array}$ & & $\begin{array}{l}0.2124^{\star * *} \\
(0.044)\end{array}$ & $\begin{array}{c}0.2267^{\star * *} \\
(0.056)\end{array}$ & $\begin{array}{l}0.2203^{\star * *} \\
(0.038)\end{array}$ & $\begin{array}{c}0.2214^{\star * *} \\
(0.038)\end{array}$ & $\begin{array}{c}0.2195^{\star * *} \\
(0.037)\end{array}$ \\
\hline UCC (t-1) & $\begin{array}{l}0.0313 \\
(0.199)\end{array}$ & & $\begin{array}{r}-0.0316 \\
(0.169)\end{array}$ & $\begin{array}{l}-0.1246 \\
(0.183)\end{array}$ & $\begin{array}{l}-0.1662 \\
(0.154)\end{array}$ & $\begin{array}{l}-0.1634 \\
(0.150)\end{array}$ & $\begin{array}{r}-0.1620 \\
(0.160)\end{array}$ \\
\hline $\begin{array}{l}\text { Equilibrium correction } \\
\text { term (t-1) }\end{array}$ & & $\begin{array}{c}-0.2663^{\star \star *} \\
(0.040)\end{array}$ & & & & & \\
\hline$\Delta$ Share price & & $\begin{array}{r}-0.0025 \\
(0.015)\end{array}$ & & $\begin{array}{l}-0.0094 \\
(0.017)\end{array}$ & & & \\
\hline$\Delta$ Profits & & & & $\begin{array}{l}0.0231 \\
(0.015)\end{array}$ & & & \\
\hline Profits (t-1) & & & & $\begin{array}{l}0.0201 \\
(0.013)\end{array}$ & & & \\
\hline$\Delta$ Uncertainty & & & & & & $\begin{array}{l}0.0014^{\star} \\
(0.001)\end{array}$ & $\begin{array}{l}-0.0002 \\
(0.002)\end{array}$ \\
\hline Uncertainty (t-1) & & & & & $\begin{array}{l}-0.0765 \\
(0.527)\end{array}$ & $\begin{array}{l}0.0002 \\
(0.001)\end{array}$ & $\begin{array}{l}0.0003 \\
(0.002)\end{array}$ \\
\hline Constant & $\begin{array}{c}-2.4684^{\star \star} \\
(1.062) \\
\end{array}$ & $\begin{array}{c}-0.7243^{\star \star *} \\
(0.119) \\
\end{array}$ & $\begin{array}{r}-0.9836 \\
(0.969) \\
\end{array}$ & $\begin{array}{l}-0.7643 \\
(0.975) \\
\end{array}$ & $\begin{array}{c}-1.2797^{*} \\
(0.660) \\
\end{array}$ & $\begin{array}{c}-1.2893^{*} \\
(0.696) \\
\end{array}$ & $\begin{array}{r}-1.2411 \\
(0.701) \\
\end{array}$ \\
\hline Observations & 1,069 & 1,069 & 780 & 1,035 & 1,069 & 1,069 & 1,069 \\
\hline Number of countries & 13 & 13 & 13 & 13 & 13 & 13 & 13 \\
\hline \multicolumn{8}{|l|}{ Tests of long-run coefficients ${ }^{1}$} \\
\hline Investment $=-$ Output & 3.130 & & 0.339 & 0.0137 & 1.883 & 1.721 & 1.484 \\
\hline $\mathrm{p}$-value & 0.077 & & 0.571 & 0.909 & 0.195 & 0.214 & 0.247 \\
\hline Investment $=-$ Output $=$ UCC & 3.250 & & 0.457 & 0.240 & 1.651 & 1.501 & 0.885 \\
\hline $\mathrm{p}$-value & 0.197 & & 0.644 & 0.790 & 0.233 & 0.262 & 0.438 \\
\hline
\end{tabular}

1. A chi-squared test is used for the System GMM model and F-tests for the others.

Note: See Table A.1 for a description of the variables. The equilibrium correction term is calculated as the difference between investment and its long-run equilibrium level given by output and the user cost of capital in period $\mathrm{t}-1$. Coefficients on country dummy variables are not shown; United States is the base country. Robust standard errors clustered by country shown in parentheses. ${ }^{* * *}$ $p<0.01,{ }^{*}{ }^{*} p<0.05,{ }^{*} p<0.1$. Joint tests for System GMM models report the Chi-squared test statistic.

Source: Authors' calculations. 
Figure A1. Estimated contributions to the change in investment growth Year-on-year percentage changes

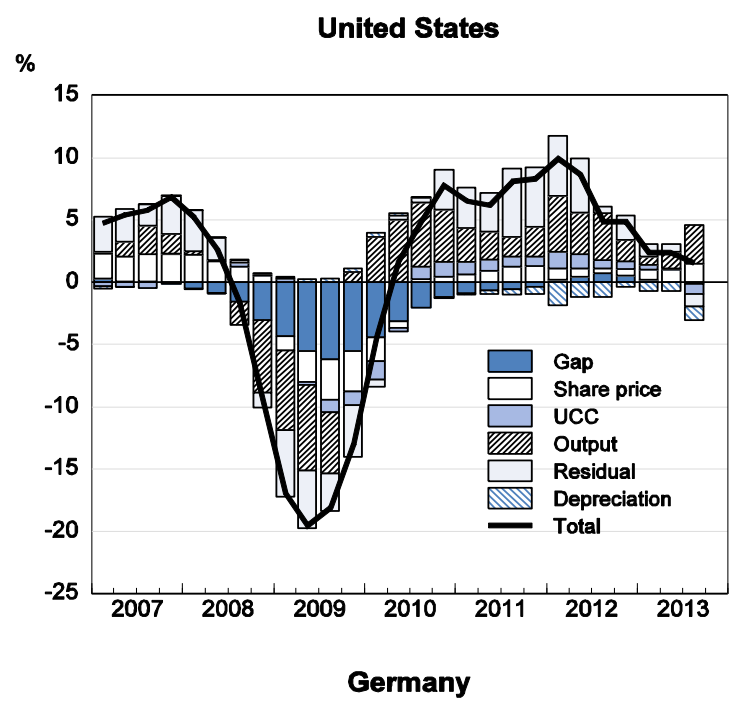

$\%$
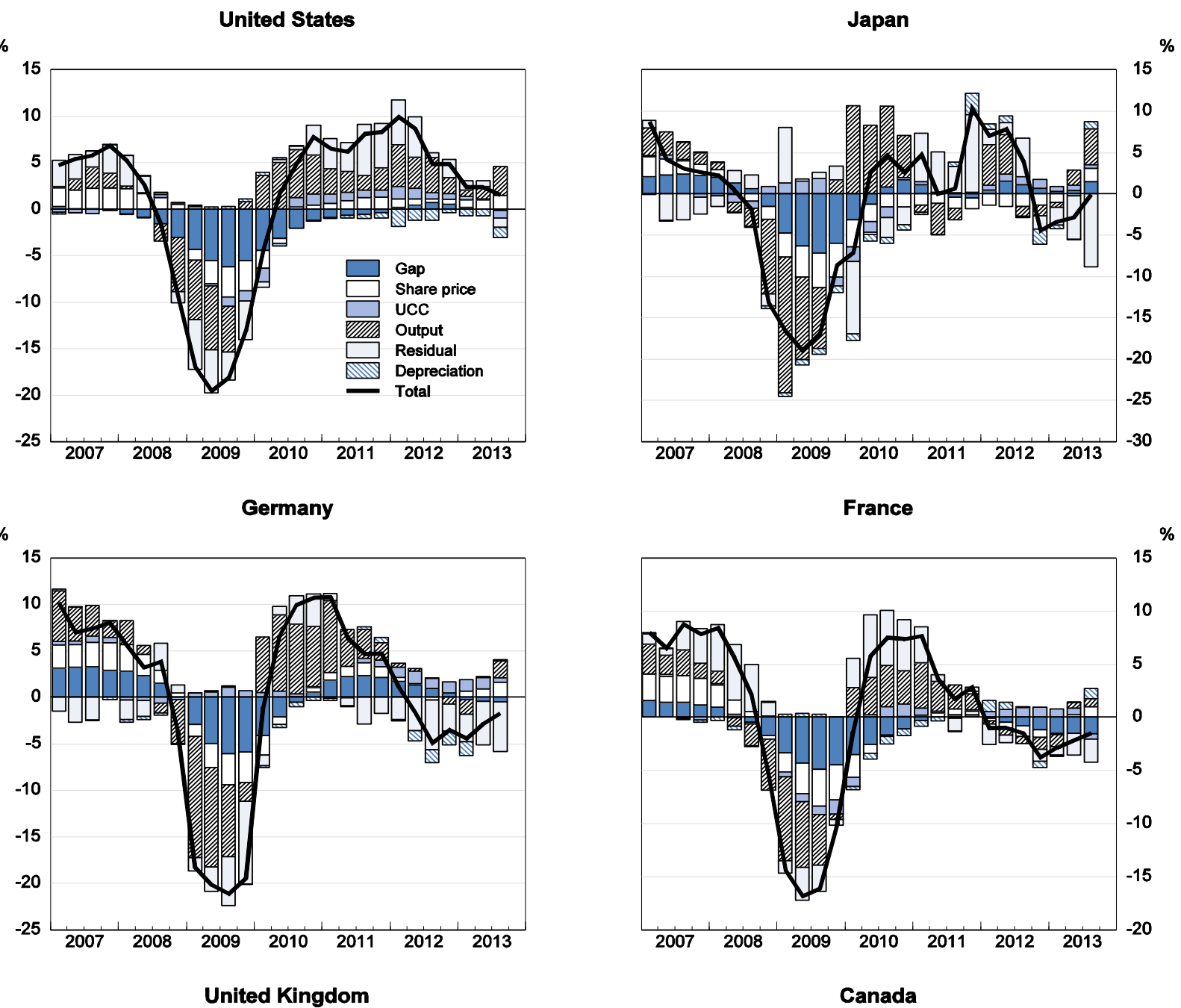

$\%$

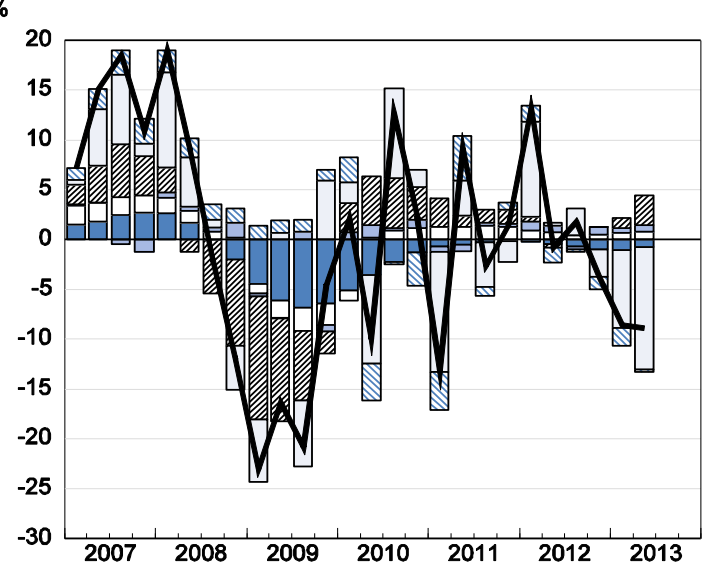

France
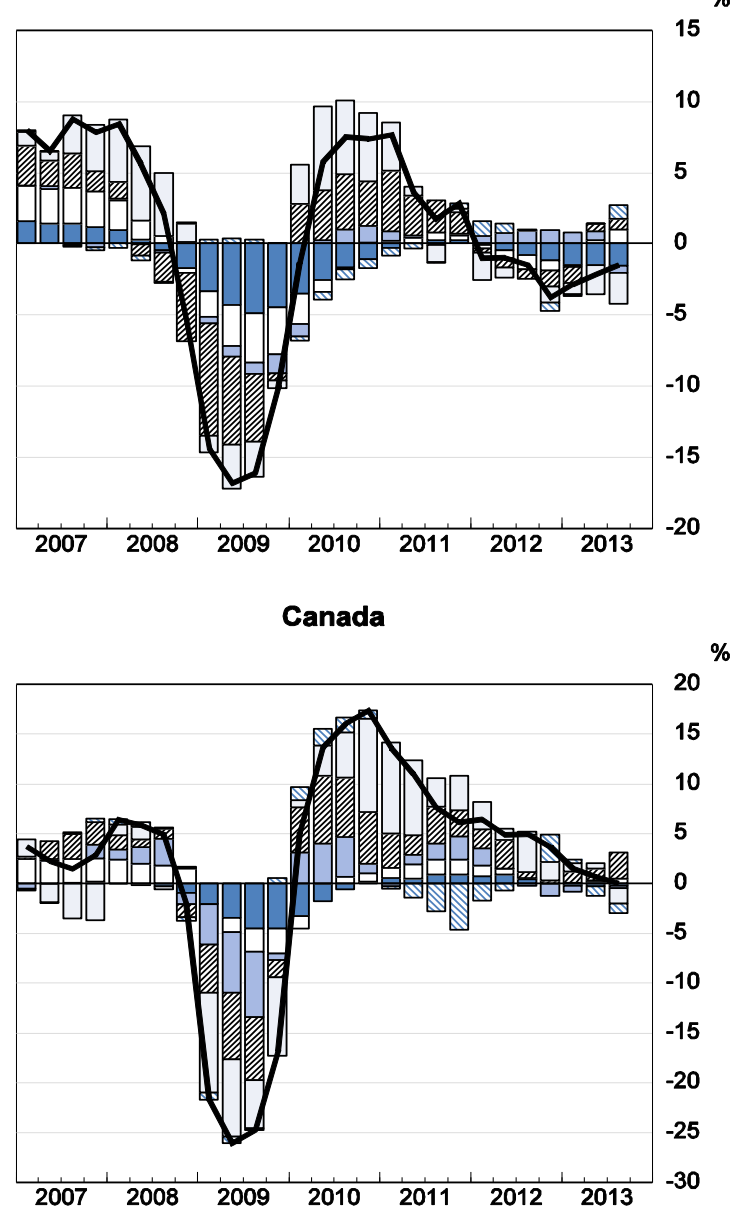

Source: OECD calculations 
Figure A1. Estimated contributions to the change in investment growth (Cont.)

Year-on-year percentage changes
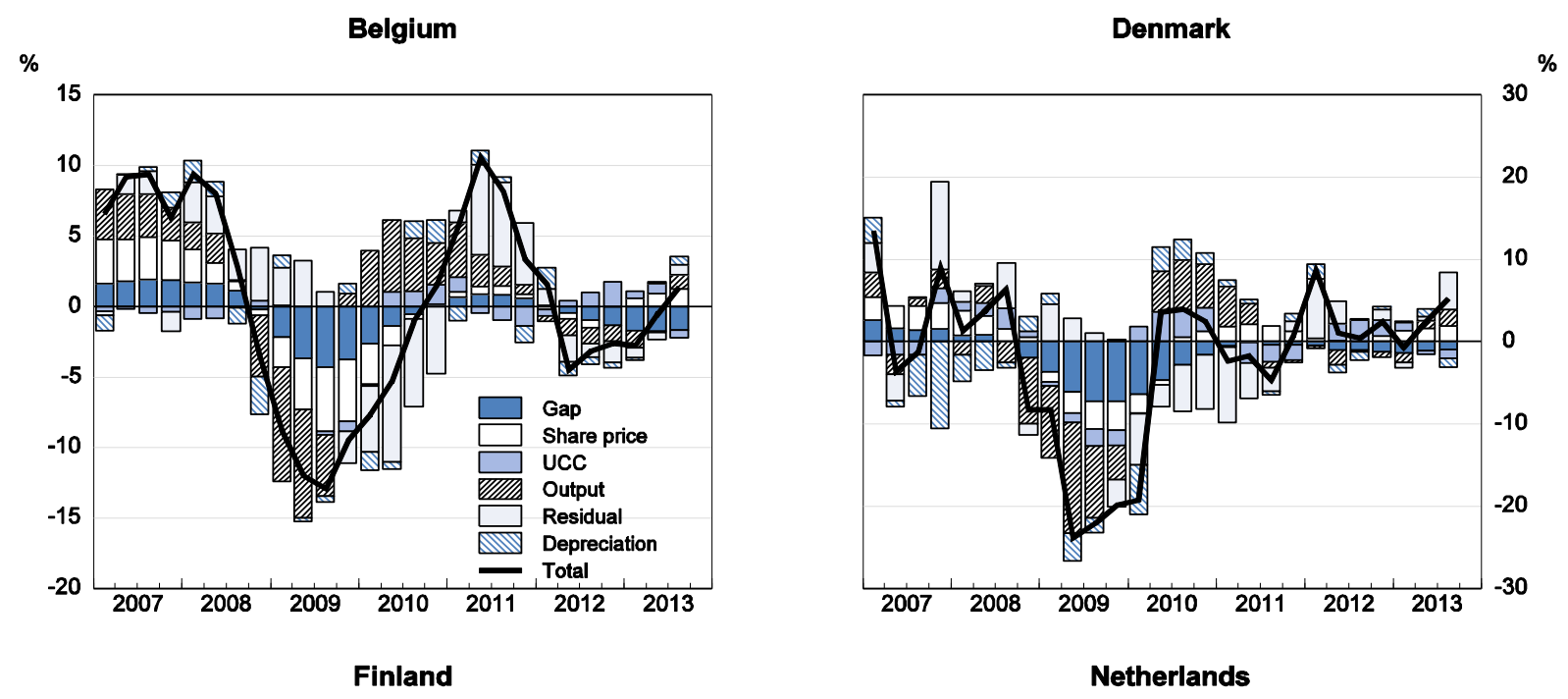

$\%$
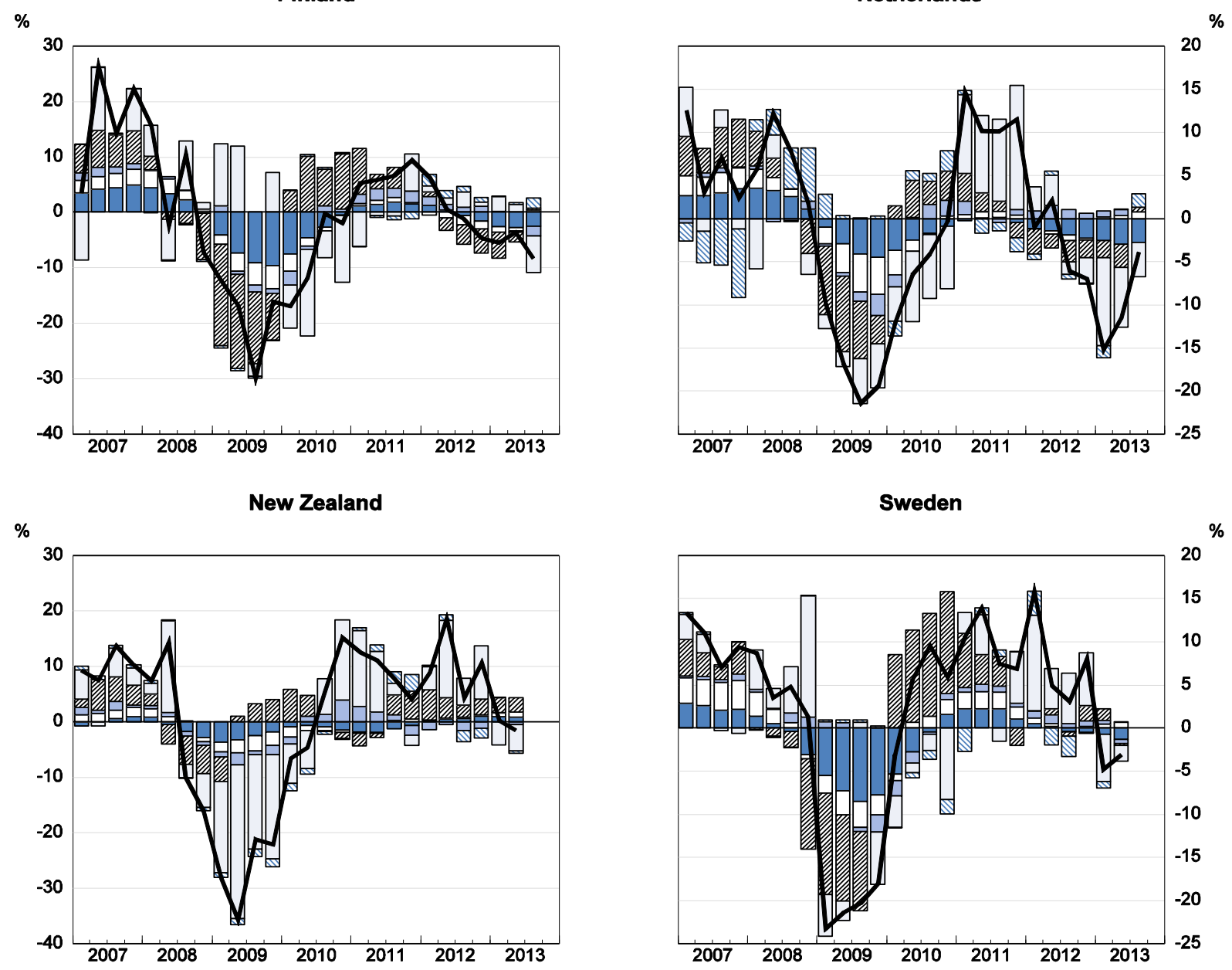

Source: OECD calculations. 


\section{WORKING PAPERS}

The full series of Economics Department Working Papers can be consulted at www.oecd.org/eco/workingpapers

1167. Factors behind the decline in real long-term government bond yield

(October 2014) by Romain Bouis, Kei-Ichiro Inaba, Łukasz Rawdanowicz and

Ane Kathrine Christensen

1166. The effect of the global financial crisis on the OECD potential output

(October 2014) by Patrice Ollivaud and David Turner

1165. Determinants of households' investment in energy efficiency and renewables - evidence from the OECD Survey on household environmental behaviour and attitudes

(October 2014) by Nadia Ameli and Nicola Brandt

1164. Addressing high household debt in Korea

(September 2014) by Randall S. Jones and Myungkyoo Kim

1163. Reducing the high rate of poverty among the elderly in Korea

(September 2014) by Randall S. Jones and Satoshi Urasawa

1162. Promoting the financing of SMEs and start-ups in Korea

(September 2014) by Randall S. Jones and Myungkyoo Kim

1161. Fostering inclusive growth by promoting structural change in the business sector (September 2014) by Rauf Gönenç, Oliver Röhn, Vincent Koen and Fethi Öğünç

1160. Reducing macroeconomic imbalances in Turkey

(September 2014) by Oliver Röhn, Rauf Gönenç, Vincent Koen and Evren Erdoğan Coşar

1159. Reinvigorating the EU Single Market

(September 2014) by Jean-Marc Fournier.

1158. An exploration of the determinants of the subjective well-being of Americans during the great recession

(August 2014) by Aida Caldera Sánchez and Caroline Tassot.

1157. Boosting the development of efficient SMEs in the Netherlands (September) by Rafał Kierzenkowski and Jochebed Kastaneer

1156. Making the banking sector more resilient and reducing household debt in the Netherlands (September 2014) by Rafał Kierzenkowski, Olena Havrylchyk and Pierre Beynet

1155. US long term interest rates and capital flows to emerging economies (July 2014) by Eduardo Olaberria

1154. Productivity measurement with natural capital and bad outputs (July 2014) by Nicola Brandt, Paul Schreyer and Vera Zipperer

1153. Reducing income inequality and poverty and promoting social mobility in Korea (July 2014) by Randall S. Jones and Satoshi Urasawa 
1152. Fostering a creative economy to drive Korean growth

(July 2014) by Randall S. Jones and Myungkyoo Kim

1151. Economic uncertainties and their impact on activity in Greece compared with Ireland and Portugal

(July 2014) by Jan-David Schneider and Claude Giorno

1150. Workplace stress in the United States: issues and policies

(July 2014) by Michael Darden

1149. Taxing the rent of non-renewable resource sectors: a theoretical note

(July 2014) by Julien Daubanes and Saraly Andrade de Sá

1148. Health, work and working conditions: a review of the European economic literature

(July 2014) by Thomas Barnay

1147. Making the best of new energy resources in the United States

(July 2014) by Douglas Sutherland

1146. Improving well-being in the United States

(July 2014) by Aida Caldera Sánchez, Patrick Lenain and Sarah Fléche

1145. Deconstructing Canada's housing markets: finance, affordability and urban sprawl

(July 2014) by Calista Cheung

Restructurer les marchés canadiens du logement : financements, accessibilité financière et étalement urbain

(Juillet 2014) par Calista Cheung

1144. Women's role in the Swiss economy

(July 2014) by Richard Dutu

Le rôle des femmes dans l'économie suisse

(Juillet 2014) par Richard Dutu

1143. Overcoming skills shortages in Canada

(July 2014) by David Carey

Combler les pénuries de compétences au Canada

(Juillet 2014) par David Carey

1142. Trade patterns in the 2060 world economy

(July 2014) by Jean Chateau, Lionel Fontagné, Jean Fouré, Åsa Johansson and Eduardo Olaberria

1141. The Demand for Skills 1995-2008: A global chain perspective

(July 2014) by Bart Los, Marcel P. Timmer and Gaaitzen J. De Vries

1140. International migration: The relationship with economic and policy factors in the home and destination country

(July 2014) by Ben Westmore 